\title{
FROM THE CHRIST-KILLER TO THE LUCIFERIAN: THE MYTHOLOGIZED JEW AND FREEMASON IN LATE NINETEENTH- AND EARLY TWENTIETH-CENTURY ENGLISH GATHOLIC DISGOURSE
}

\author{
Simon Mayers*
}

\begin{abstract}
Conventional wisdom in studies of English antisemitism has tended to suggest that by the nineteenth century religious prejudice had largely been secularised or replaced by modern sociopolitical and racial forms of hostility. This may have been the case in the general English discourse, but in the English Catholic discourse at the turn of the twentieth century, traditional pre-modern myths, with their cast of Jewish and Masonic diabolists, were still a pervasive feature. This article examines a range of sources, including the published works of prominent and obscure authors, the pastoral letters and sermons of cardinals, bishops and priests, articles and editorials in newspapers and periodicals, letters, and a small number of oral testimonies, in order to bring to light an English Catholic discourse which, with the exception of the published works of Hilaire Belloc and G. K. Chesterton, has largely gone unexamined. Prominent mythological villains in the English Catholic discourse during the late nineteenth- and early twentieth-century included "the Pharisee," "the Christ-Killer," "the Ritual Murderer," "the Sorcerer," "the Antichrist" and "the Luciferian." This article examines the continued presence of narratives in which Jews and Freemasons were assigned one or more of these villainous roles.
\end{abstract}

This article presents some of the results of an investigation into the representations of "the Jew" which existed in English Catholic discourse during the final years of the nineteenth century and the early decades of the twentieth century (circa 1896 to 1929). Three main types of representation were considered during the investigation: the roles assigned to the Jew in traditional Christian myths, contemporary stereotypes of the Jew and composite constructions which combine themes drawn from myths and stereotypes. ${ }^{1}$ For the purpose of the investigation, stereotypes were broadly speaking defined as crude, powerful, resilient but protean representations, which take so-called human vices and virtues, often distorted and magnified, and project them onto all individuals within the stereotyped group. In the English Catholic discourse, the stereotyped Jew was greedy, cowardly, unpatriotic and secretive. ${ }^{2}$ He was also depicted as smart, but his intelligence was not considered a virtue. ${ }^{3}$ Myths were in essence defined in the investigation as important and persistent stories

\footnotetext{
* Awarded his PhD from the Dept. of Religions and Theology at the University of Manchester in 2012. E-mail: simonmayers@hotmail.com

1 The distinction between these types of representation is discussed in more detail in: Simon Mayers, "From 'the Pharisee' to 'the Zionist Menace': Myths, Stereotypes and Constructions of the Jew in English Catholic Discourse (1896-1929)," PhD thesis, University of Manchester (2012), ch.1.

2 These stereotypes are examined in Mayers, "From 'the Pharisee' to 'the Zionist Menace,'” ch.3.

${ }^{3}$ For example, the so-called "Hebrew genius" was portrayed as an antagonist and contrast to the "Catholic spirit" in William Barry, "Sign of the Times II," Catholic Times, 6 November 1920, 7. Hilaire Belloc argued that one
} 
of religious or cultural significance which have been treated as truthful representations of past events. Myths are resilient but adaptive narratives that serve an important psychological or sociological function, such as justifying the creation and ongoing existence of a religion or culture, or the usurpation and suppression of a rival religious and cultural group. ${ }^{4}$ In the English Catholic discourse, the mythologized Jew was a stubborn Pharisee, the rejecter and murderer of Christ, a ritual murderer, a sorcerer and the Antichrist.

Whilst the term "construction" has been used in various ways in studies examining how discourses shape reality, it was used in this investigation to specifically signify distinct composite creations which combine contemporary stereotypes and traditional myths. ${ }^{5}$ Whilst individual authors created their own constructions, ${ }^{6}$ a pervasive construction in the English Catholic discourse was the "Masonic-Jewish Camarilla."7 "The Freemason" was stereotyped as a secretive, plundering, unpatriotic, anti-social, anti-national, anti-Christian agitator and mythologized as a Lucifer-worshipping, host-desecrating diabolist. In these constructions the Jew was often depicted as the ally and fellow conspirator of the Freemason. Of the three types of representation examined in the investigation, the focus in this article is the mythologized Jew and the mythological component of constructions of the "MasonicJewish Camarilla."

Conventional wisdom in studies of English antisemitism and Anglo-Jewish history has tended to suggest that by the nineteenth century religious prejudice had largely been secularised or replaced by modern socio-political and racial forms of hostility. ${ }^{8}$ This may

of the marks of the Jew is the "lucidity of his thought." He was "never muddled" in argument and his inescapable reasoning thus has in it "something of the bully." A man arguing with a Jew, Belloc contended, may know the Jew to be wrong, but his "iron logic" is "offered to him like a pistol presented at the head of his better judgement." Hilaire Belloc, The feres (London: Constable, 1922), 81.

${ }^{4}$ According to Hyam Maccoby, on the surface the Christian foundation myth is not dissimilar in function to the "dispossession" or "usurpation" myths of other civilisations. Maccoby explains that in the case of the Christian "usurpation myth," the "very self-image of a community" was the "target of a take-over bid." Rather than a mere territorial usurpation, the myth has been used to "annex the position of being the true Israel." Maccoby suggests that the Christian "usurpation myth" is uniquely complex, consisting of a "multiplicity of mythological motifs." A distinctive feature is that the usurped characters, i.e. the Jews, have been assigned an important "continuing role within the landscape of the Christian myth." Hyam Maccoby, A Pariah People: The Anthropology of Antisemitism (London: Constable, 1996), 63-65, 82-115; Hyam Maccoby, The Sacred Executioner: Human Sacrifice and the Legacy of Guilt ([London]: Thames and Hudson, 1982), 134.

${ }^{5}$ One study which uses the term "construction" in a different way to this investigation is Bryan Cheyette's Constructions of "the Jew" in English Literature and Society: Racial Representations, 1875-1945 (Cambridge: Cambridge University Press, 1993). According to Cheyette, there was a "bewildering variety of contradictory and overdetermined representations of "the Jew." Cheyette suggests that these contradictions were so extreme that they were "particularly threatening to those who would wish to exert a sense of control and order over an increasingly unmanageable "reality." Whereas this investigation examines structures of discourse, Cheyette focuses on the absence of structure. He argues that constructions of the Jew were "radically unstable," "indeterminate," "ambivalent," "contradictory," "over-determined" and "fluid" (8-9, 268-269). However, in this investigation, whilst the potential permutations of composite constructions based upon stereotypes and myths were large, the reality was that the constructions of the Jew of one English Catholic author were rarely radically different to those of another; they were varied and distinct, but there were always points of similarity, and they were by no means protean to the point of being fluid.

${ }^{6}$ For example, Canon William Barry, a prominent English Catholic priest and author, drew upon stereotypes of Jewish greed, foreignness and secrecy, and myths about a Judeo-Masonic conspiracy and the Jewish Antichrist, to produce his own distinctive construction of the Jew.

7 The other pervasive composite construction of the Jew in the English Catholic discourse was "the Zionist Menace."

${ }^{8}$ See for example: Todd M. Endelman, The Jeres of Britain, 1656 to 2000 (Berkeley: University of California Press, 2002), 67-71; Todd M. Endelman, The Jewes of Georgian England, 1714-1830 (Philadelphia: Jewish Publication 
well have been the case in the general English discourse, but conversely, in the English Catholic discourse at the turn of the twentieth century, traditional myths, with their cast of Jewish and Masonic diabolists, were still a pervasive feature. This article examines the main guises of these persistent mythological villains: the Pharisee, the Christ-Killer, the Ritual Murderer, the Sorcerer, the Antichrist and the Luciferian.

\section{The Pharisee and the Christ-Killer}

At the dawn of the Christian era, the foundation was established for a complex and protean myth: the long awaited Jewish messiah whose coming was foretold in the Hebrew Scriptures was rejected and killed by the Jews. Two key roles, sometimes rendered distinct but often conjoined, were assigned to the Jews in this myth. The first role, "the Pharisee," was depicted as blind, arrogant, stubborn, mean, manipulative, hypocritical and legalistic. According to the foundation myth, the Pharisee would not embrace the truth of God's new covenant. ${ }^{9}$ The second role, "the Christ-Killer," was the paramount villain of all time, who rejected, hounded and called for the death of the messiah. According to the myth, by rejecting the messiah and the new covenant, the Jews rejected God. God in turn rejected them, and replaced them with the Church as the "new Israel."

The most common source within the English Catholic discourse for the Pharisee and the Christ-Killer were the sermons and pastoral letters of priests and bishops. Selective elements from traditional myths were drawn upon to make salutary points about Christian virtues and non-Christian vices. One of the masters of this form of sermon was a prominent convert from the Anglican to the Catholic Church, Ronald Knox, a celebrated priest, theologian and novelist. ${ }^{10}$ Many of his sermons have been collected into volumes and published. His sermons were often peppered with references to Jews and Pharisees, especially those dealing

Society of America, 1979), 86-117; Anthony Julius, Trials of the Diaspora: A History of Anti-Semitism in England (Oxford: Oxford University Press, 2010), 245-246; Frank Felsenstein, Anti-Semitic Stereotypes: A Paradigm of Otherness in English Popular Culture, 1660-1830 (1995; repr., London: John Hopkins University Press, 1999), 25-26. Conversely, whilst Tony Kushner has suggested that "a delicate sense of balance" is needed when discussing the importance of the blood libel in Britain by the time of the Second World War, he also observed that the representations of the Jew as deicide and ritual murderer, and the image of the Jew with horns on his head, had not entirely disappeared. Kushner concluded that "the legacy of the middle ages had thus survived, albeit more commonly in a watered down and confused form." Tony Kushner, The Persistence of Prejudice: Antisemitism in British Society During the Second World War (Manchester: Manchester University Press, 1989), 106-109. See also Colin Holmes, Anti-Semitism in British Society, 1876-1939 (New York, Holmes \& Meier, 1979), 62, 251-252n90.

9 Trachtenberg points out that it was believed by some Christians that the Jews were wilful rather than ignorant in their rejection. For example, some early Church Fathers, such as Jerome and Justinian, complained that the Rabbis "deliberately perverted the meaning of the original text." Medieval scholars even accused Jews of "tampering with the text of the Bible in an effort to destroy its Christological meaning." Joshua Trachtenberg, The Devil and the Fews: The Medieval Conception of the Few and its Relation to Modern Antisemitism (1943; Philadelphia: Jewish Publication Society, 1983), 15, 153.

${ }^{10}$ Ronald Knox (1888-1957) was a close friend of Hilaire Belloc and G. K. Chesterton. Knox was born into a wealthy Anglican family. His father, Edmund Knox, was the Anglican Bishop of Manchester. Knox was ordained an Anglican priest in 1912, converted to Roman Catholicism in 1917 and was ordained a Roman Catholic priest in 1919. His sermons were crafted with meticulous care, highly articulate and in demand. According to Kevin Morris and Ulrike Ehret, Knox developed sympathies for fascism, though he subsequently opposed Nazism (as it infringed upon the rights of the Church). Kevin L. Morris, "Fascism and British Catholic Writers 1924-1939," Chesterton Review, XXV, no. 1 \&2 (February 1999), 31, 38; Ulrike Ehret, "Catholics and Antisemitism in Germany and England, 1918-1939," PhD thesis, University of London (2006), 177. 
with the parables of Jesus. According to Knox, "the Pharisee" in Jesus' parables represents "the Jews, and especially the strict Jews." ${ }^{\prime 1}$ He argued that the Pharisees were full of "pride and blindness," 12 trusted in their "own righteousness" 13 and "misinterpreted the meaning of the old dispensation." "The Pharisees," Knox concluded, "could not accept Christ" because of "their hatred of everything Gentile" and their "blind traditional interpretations of the law." "The Jews had rejected their God" and so "God rejects his people." Knox explained that "the Jews have so long been accustomed to being the sole beneficiaries of God's covenant with man that it seems incredible to them now that God should be able to do without them." 15 According to Knox, as the Pharisees listened to the parables of Jesus, they were sure there was something blasphemous about them, something that could only "be expiated by a cross." When they realised that Jesus was "speaking of them," the only thing that prevented them seizing Him there and then was their fear of "the multitude." This was, he suggested, the "prelude to Gethsemane and to Calvary." "God's patience," he stated, "lasts very long," and thus he did not reject "the Jews" until they "crowned their apostasy with the murder of his own Son." 17 Knox repeated these narratives in articles published in The Cross, the periodical of the Passionists based in Dublin. ${ }^{18}$ He suggested that the Pharisees were obsessed with fulfilling "the old law." Christians should, he argued, go beyond "the Scribes and Pharisees," not by adding "a series of codicils, as lifeless, as uninspiring as the rest." They should not add even more rules, but carry out God's commandments "in the spirit" rather than "in the letter." His point was that unlike the Pharisees, "Christians ought to have a law, written not on tables of stone, but on our inmost hearts; a principle of active charity which ought to supersede the necessity for commandments." ${ }^{19}$

Since the early centuries of the Christian era, a variety of Jews have been held accountable for crucifying Christ, and often this multiplicity would be found in a single narrative. This was also the case in the modern English Catholic discourse. For example, Knox explained that it was not just the "Pharisees" who "rejected and crucified our Lord." The Jewish "Zealots" expected a military leader. They were ready to support Jesus until "they discovered that his kingdom was not of this world" and that his warfare would not be "against the Roman oppressor." The "Sadducees" considered Jesus "a political menace." According to Knox, whichever type of Jew they were, fanatical Zealot, obscurantist Pharisee or worldly Sadducee, "they all crucify Christ." ${ }^{20}$ Father Bernard Vaughan, brother of Cardinal Archbishop Vaughan, was a popular clergyman in his own right, and like Knox, his sermons

${ }^{11}$ Ronald Knox, "Grace and Good Works," in The Mystery of the Kingdom (London: Sheed \& Ward, 1928), 98-99. This sermon and all the other Knox sermons cited from The Mystery of the Kingdom were delivered at the Carmelites' Church in Kensington and published in 1928.

12 Ronald Knox, "The Incarnation" (1928), in Mystery of the Kingdom, 13-14.

13 Ronald Knox, "Equality of Reward" (1928), in Mystery of the Kingdom, 120.

14 Ronald Knox, "Parable" (1928), in Mystery of the Kingdom, 8.

15 Ronald Knox, "Reprobation" (1928), in Mystery of the Kingdom, 80-83.

16 Ronald Knox, "Parable" (1928), in Mystery of the Kingdom, 3-4.

17 Ronald Knox, "Equality of Reward" (1928), in Mystery of the Kingdom, 119.

${ }_{18}$ The Passionists are members of a Catholic order (the Congregation of Discalced Clerks of the Most Holy Cross and Passion of Our Lord Jesus Christ), founded in the eighteenth century. The Cross often contained articles by prominent English Catholics, including Knox, Belloc and G. K. Chesterton.

${ }_{19}$ Ronald Knox, "Angry?," The Cross, XVII, no. 12 (April 1927), 396-397; Ronald Knox, "Danger versus Safety," The Cross, XVIII, no. 2 (June 1927), 40.

${ }^{20}$ Ronald Knox, "Reprobation" (1928), in Mystery of the Kingdom, 80-81. 
were in demand all over the country. ${ }^{21}$ Also like Knox, he explained that all varieties of Jews were responsible for the murder of Christ. In an address delivered at the Church of the Immaculate Conception in 1907, he stated that "Priests and Levites, Pharisees and Scribes, Sadducees and Herodians, servants and soldiers, young men and women, and children innumerable, all came forth to see the end, the crucifixion and death of Jesus Christ." Invoking the moment for his audience, he asked them to "picture for one moment the wild and mad Eastern mob, tossing to and fro, screaming and gesticulating in their flowing garments of every shade." He observed that "they are, most of them at any rate, discussing the situation, and congratulating one another on the verdict which rids their nation of another arch imposter." 22

Sermons by other priests also referred to the rejection of Christ. For example, Father Bede Jarrett, the head of the English Dominicans and the founder and president of the Catholic Guild of Israel, combined the Pharisee and the Christ-Killer in a sermon delivered in 1915. According to a report of this sermon in the Catholic Times, Jarrett pointed out that Christ was "done to death" as a result of a "political accusation." According to Jarrett, the noteworthy thing was that Christ was "accused by the Pharisees because He adopted their political ideas." His teachings were too pure and sincere for the Pharisees and so, in their "sheer hypocrisy," they denied their own politics in order to denounce Him. ${ }^{23}$ A sermon in 1915 by the auxiliary Bishop of Salford, John Stephen Vaughan (another brother of the Cardinal Archbishop), stated that when the world goes astray and "is in danger of forgetting Him, God does not abandon it, but He rises up and visits it with the most unmistakable signs of His displeasure." As an example he cited the fate of the Jews: God summoned up "the Romans with their armies," and used them to wrought destruction upon Jerusalem, "in punishment of the sins and crimes of the perfidious Jews." 24

In addition to these sermons, the follies of Jewish "legalism" and the rejection of Christ also featured in the carefully constructed pastoral letters of the bishops and archbishops of the English hierarchy. ${ }^{25}$ Edward Ilsley, the first Archbishop of Birmingham, one of the largest and most important Roman Catholic divisions in England, referred to the Jews in a number of his pastoral letters. ${ }^{26}$ In his mid-Lent pastoral for 1916, he stated that the Jewish

\footnotetext{
${ }^{21}$ Edward Cruise, "Development of the Religious Orders," in George Andrew Beck, ed., The English Catholics, 1850-1950 (London, Burns Oates, 1950), 455-456.

${ }_{22}$ Bernard Vaughan, Society, Sin and the Saviour (London: Kegan Paul, Trench, Trübner, 1908), 183-184.

23 "Christ or Caesar: Sermon by Father Bede Jarrett, O.P.," Catholic Times (London edition only), 29 October 1915, 7. The sermon was delivered at St James' Roman Catholic Church, Spanish Place, London. Bede Jarrett (1881-1934) was the head of the English Dominicans from 1916 onwards. He founded the Catholic Guild of Israel in 1917 in order to improve efforts to convert the Jews in England.

${ }^{24}$ John Stephen Vaughan, "The Scourge of War," The Catholic Pulpit, Universe, 13 August 1915, 6. This sermon was delivered at Salford Cathedral on 5 August 1915. John Stephen Vaughan (1853-1925) was the youngest brother of Cardinal Archbishop Vaughan. He was the auxiliary Bishop of Salford.

${ }^{25}$ For a nuanced discussion of "legalism," see Bernard Jackson, "Legalism," Fournal of Fewish Studies, XXX, no.1, Spring 1979, 1-22. Jackson observes that the notion of "legalism" is a Christian concept and one that ideally neither Jews nor lawyers would have to deal with.

${ }^{26}$ Edward Ilsley (1838-1926) was Bishop (1888-1911) and Archbishop of Birmingham (1911-1921). After the reintroduction of the Catholic hierarchy in 1850, England consisted of one ecclesiastical province (the Archdiocese of Westminster and several suffragan dioceses). Due to rapid growth, the Catholic Church in England was reorganised in 1911 into three ecclesiastical provinces (Westminster, Birmingham and Liverpool). Francis Bourne, the Archbishop of Westminster, was made a Cardinal at the same time. Ironically, Bourne had less power as Cardinal-Archbishop than he did previously. The Archbishop of Westminster continued to enjoy certain privileges, but he was now in effect the first amongst three equals. Bourne sought permission to use the title, "Primate of
} 
sacrifices could have but little efficacy for the "remission of sins." "At the best they came from a tainted source," he stated, and "possessed no worth which could make them pleasing to God." The sacrifices of "the Old Law," he maintained, "availed only to give the Jews an external, ceremonial purification, but were powerless to cleanse the soul from sin." 27 In a pastoral for Quinquagesima Sunday in 1916, Ilsley stated that God repeatedly visited "the infidelities of the Jewish people with the scourge of war and of pestilence, and finally of national ruin and rejection." This was because they "repeatedly rejected Him." ${ }^{28}$ Ilsley referred back to this pastoral letter in the following year, pointing out again that "the history of the human race, and especially of the Jewish nation, brings home to us the truth that Almighty God punishes sin not only in the next life, but also in this." "Time after time the infidelities of the Jewish people," Ilsley stated, "were visited by the death of thousands." ${ }^{29}$ In another pastoral letter, Ilsley declared that "the revealed truth of the Divinity of Christ was denied and called in question from its first affirmation." He stated that "the Jews, of course, refused to believe it." ${ }^{30}$ Archbishop John McIntyre, Ilsley's friend and assistant for many years and his successor at Birmingham, similarly stated that, "God turned to the Gentiles and called them to inherit His ancient promises which the Jews had fallen away from by reason of their infidelity." 31

Pastorals by many other bishops referred or alluded to the murder of Christ and the emptiness of Jewish legalism. William Gordon, the Bishop of Leeds, did not explicitly link the "awful death of Calvary" to the Jews, but he did state that on the night before his death, he closed "the Jewish dispensation" and instituted "the New Covenant with His Christian people." 32 George Ambrose Burton, the Bishop of Clifton, alluding to a passage in Luke 18:32, stated that: "He shall be delivered to the Gentiles, and shall be mocked, and scourged, and spit upon; and after they have scourged Him, they will put him to death." Burton went on to state that the Passion of Christ continues to hold an "abiding significance" even though it has been "some two thousand years since the wild shouts of the Jewish people filled Pilate's praetorium." ${ }^{33}$ William Cotter, the Bishop of Portsmouth, stated in 1916, that "it would be a great mistake to suppose that by the mere exterior act of fasting, we should fulfil all our obligations to Almighty God." "The Jews," Cotter continued, "fasted even according to the letter of the precept; but God answered them with a reproach." The important point is not,

England and Wales," in order to solidify his position. Archbishop Ilsley, one of two new archbishops, was one of the leading voices of objection. Bourne was not granted the title of Primate and over the following years a heated rivalry developed between Bourne and Ilsley over the boundaries of the dioceses. See Mary McInally, Edward Ilsley: Archbishop of Birmingham (London: Burns \& Oates, 2002), 309-329, 342-344.

${ }^{27}$ Edward Ilsley, pastoral letter, Mid-Lent Sunday 1916, pp.6-7, Birmingham Archdiocesan Archives.

${ }^{28}$ Edward Ilsley, pastoral letter, Quinquagesima Sunday 1916, p.5, Birmingham Archdiocesan Archives. Quinquagesima Sunday was the Sunday before Ash Wednesday (fifty days before Easter Day). The term has largely fallen out of use since Vatican II.

${ }^{29}$ Edward Ilsley, pastoral letter, Quinquagesima Sunday 1917, pp.3-4, Birmingham Archdiocesan Archives.

${ }_{30}$ Edward Ilsley, pastoral letter, Last Sunday after Pentecost 1916, p.5, Birmingham Archdiocesan Archives.

31 John McIntyre, pastoral letter, Sixteenth Sunday after Pentecost 1922, p.95, Birmingham Archdiocesan Archives. John McIntyre (1855-1934) was Archbishop of Birmingham from 1921-1928. See Who Was Who, 1929 1940 (London: Adam \& Charles Black, 1941), 861.

32 William Gordon, pastoral letter, Advent 1901, p.4, Acta Ecclesiae Loïdensis, vol. XI, Leeds Diocesan Archives. Gordon (1831-1911) was born in Thirsk, North Yorkshire, ordained a priest in 1856 and was appointed Bishop of Leeds in 1890.

${ }^{33}$ George Ambrose Burton, pastoral letter, Lent 1905, p.9, Acta Episcoporum Angliae, Salford Diocesan Archives. George Ambrose Burton (1852-1931) was ordained a priest in 1890 and appointed Bishop of Clifton in 1902. See Who Was Who, 1929-1940, 197. 
he suggested, to observe every rigour of the law with proud passion, but rather to fulfil the spirit of the law with humility and "deep sorrow for our sins." " In 1924, Cotter informed his flock, that "in the story of the passion of Our Lord there is an incident which causes us a special horror." According to Cotter, "when the Jews were offered by Pontius Pilate the choice between Jesus and Barabbas," they shouted out, "take away Jesus: let him be crucified." This incident should, he suggested, cause us to "shudder with horror." This sermon provides an example of the representation of the Jew as Christ-Killer being used to instruct Christians about the dangers of sin. Cotter suggested that Christians should not be complacent, as they too are guilty of rejecting God and turning away from Jesus every time they place their "sinful whims" over the love of God. This was, Cotter suggested, even worse than the crime of "the Jews," since they at least "knew not what they were doing." 35

These sermons and pastoral letters, for the most part repeated key aspects of traditional myths about the Jews, mainly taken or adapted from the New Testament. The main function of the mythological villains in these addresses, would seem to have been to provide a foil against which Christian virtues could be favourably contrasted. It seems unlikely that these sermons and pastoral letters were intended by their authors as templates for the deliberate stereotyping of contemporary Jews, but it is likely that these and countless sermons and pastorals just like them fulfilled an important function in preserving and replicating the myth of the Jew as a diabolic villain. In this respect they were similar in function, if milder in tone, than corresponding sermons from the early centuries of the Christian era and the Middle Ages. They helped to ensure that myths about the Pharisee and the Christ-Killer survived into the next generation.

These sermons and pastoral letters may have been ostensibly innocent, at least by intention, but the myth of the Pharisee and the Christ-Killer was sometimes formulated in such a way that the contemporary Jew became a part of the narrative. For example, Ronald Knox suggested that the character of the Jewish "race" has been shaped by their rejection of Jesus. According to a sermon by Knox, "with each fresh rejection of God's messengers the habit of rebellion has grown deeper into the Jewish heart." "Their character," he stated, has been moulded by "act after act of apostasy." 36 Another example is provided by a sermon preached at a meeting of the Catholic Guild of Israel by the Rev. Dr. Arendzen, a respected scholar, author and member of the Catholic Missionary Society. ${ }^{37}$ Arendzen argued that "the history of the world is the history of a school." "Israel," the first pupils of "God's school," had "a contempt and disdain for all the world." They would not accept the teachings of Jesus and instead "crucified him on the hill of Calvary." "The Jews" were thus replaced by "the gentiles," who "became the good school of God." Bringing the story forward to the present day, Arendzen argued that Israel "have gone their own way for these two thousand

${ }_{34}$ William Timothy Cotter, pastoral letter, Quinquagesima Sunday 1916, pp.7-8, Acta Episcoporum Angliae, Salford Diocesan Archives. Cotter (1866-1940) was born and trained as a priest in Ireland, ordained in 1892, appointed Canon of Portsmouth in 1900, and Bishop of the same diocese in 1910. See Who Was Who, 1929-1940, 291.

35 William Timothy Cotter, pastoral letter, Quinquagesima Sunday 1924, pp.5-6.

${ }^{36}$ Ronald Knox, "The Patience of God" (1928), in Mystery of the Kingdom, 62.

${ }^{37}$ Rev Dr John Arendzen (1873-1954) held a PhD from Bonn University, a Doctor of Divinity from Munich and a BA and MA from Cambridge. He was an expert in philosophy, theology and Arabic, and the author of many books and articles on religion. He was a member of the Catholic Missionary Society and the Catholic Evidence Guild. He attended a number of meetings of the Catholic Guild of Israel, though it is not clear if he attended as a guest or as a member. 
years. They still have their old school books, the old testament, and the Jews know their old testament very well in the old Hebrew language. The Jews are a proud people and they despise all others." "38 The Guild minutes described his address as "a beautiful sermon on behalf of the people of Israel." 39 Arendzen's sermon was clearly focused not only on the mythologized Jews from the traditional foundation myth, but also on contemporary Jews, who, he alleged, continue to despise all non-Jews. These sermons no longer merely replicated myths. They incorporated mythological roles (i.e. the Pharisee and the Christ-Killer) and stereotypes (i.e. prideful, disdainful, spiteful, powerful, rebellious Jews), into contemporary constructions of the Jew.

Whereas sermons and pastoral letters tended to replicate and preserve the myth of the diabolic Jewish villain, and in some exceptional cases were formulated in such a way as to generalise the villainy to contemporary Jews, the Catholic Herald conversely had a much more overt role in combining the myths with modern stereotypes in order to create a complex construction. ${ }^{40}$ Charles Diamond, the owner-editor of the Catholic Herald and a political firebrand and maverick, was not particularly concerned about the deep theological significance of the Jew in Christian myths. Diamond saw himself as a champion of Catholicism, Christian civilisation and Irish nationalism. ${ }^{41}$ It seems that he disliked Jews and Freemasons, not as a consequence of theological concerns, but because he saw them as a foreign and threatening presence within Christian civilisation. He felt that the European nations should have the right to expel the Jews. "His civilisation is not Christian," the newspaper warned, and "his ethics, his morality, are not Christian. He has a deadly hatred of Christianity." ${ }^{42}$ Whilst he was not concerned with theology per se, Diamond was happy to draw upon aspects of the Christian foundation myth in order to make his constructions of the Jew more powerful. The main function of the foundation myth for Diamond seems to

\footnotetext{
${ }^{38}$ John Arendzen, sermon, 28 November 1921, Catholic Guild of Israel Archives, Sion Centre for Dialogue and Encounter, London.

${ }^{39}$ Guild Minute Book, entry for 28 November 1921, taped into minute book at page 50, Catholic Guild of Israel Archives.

${ }^{40}$ The Catholic Herald was founded in 1893 by Charles Diamond. He owned and edited it until his death in 1934. The Catholic Herald was the most vehemently anti-Jewish of the English Catholic organs in the early twentieth century. For more about the Catholic Herald, see Owen Dudley Edwards and Patricia J. Storey, "The Irish Press in Victorian Britain," in Roger Swift and Sheridan Gilley, eds., The Irish in the Victorian City (London: Croom Helm, 1985), 172-176.

${ }^{41}$ Charles Diamond (1858-1934) was born in Ireland in 1858. He was M.P. for North Monaghan from $1892-$ 1895. He also contested districts of London for the Labour Party in 1918, 1922 and 1924. Diamond was a maverick who frequently got into trouble with the ecclesiastical authorities. He was repeatedly criticised by the English bishops, not for his hostile articles about Jews, but because he tended to disrespect and undermine their ecclesiastical authority. A resolution was passed by the bishops in 1910, expressing their distaste with the Catholic Herald, which tended to "lessen the respect due from all Catholics to ecclesiastical authority." Acta of the Bishops' Low Week and Autumn Meetings, 5 April 1910, file EP/A/1, Birmingham Archdiocesan Archives. Diamond also got into trouble with the British authorities when one of his articles suggested that a failed attempt to assassinate Lord French, the Lord Lieutenant of Ireland, should not be considered an attempted murder. He argued that the action was justified since "English government in Ireland is not government. It is simply usurpation, brutality, and oppression." As a result he spent several months in Pentonville Prison (January-August 1920). For the article that got him into trouble, see "Killing no Murder," Notes and Comments, Catholic Herald, 27 December 1919, 6-7. For an article that described his experiences in prison, see "Mr Diamond's Release: Story of His Experiences in Pentonville," Catholic Herald, 14 August 1920, 3. Diamond articulated a mixture of left-wing politics, energetic Catholicism and Irish nationalism in the Catholic Herald, which attracted a large working class Catholic readership despite his fragile relationship with the bishops. For more on Charles Diamond, see Kester Aspden, Fortress Church (Leominster, Hertfordshire: Gracewing, 2002), 33-34, 88, 96.

42 "The Jewish Question," Catholic Herald, 13 September 1919, 6.
} 
have been to give the newspaper's construction of the villainous Jew the added weight of scriptural authority. If the original function of the Christ-Killer myth was to justify the usurpation of the Jewish claim to be the true Israel, it was now used to justify the continued suppression of the Jews living in Christian society. An editorial in 1914 provides a useful example. This editorial was written in response to a report that a rabbi-chaplain had been killed whilst attending a dying Catholic soldier on the battlefield with a crucifix to ease his passing. The editorial stated that this story was improbable. It went on to suggest that there is "ample evidence" to show that most Jews are more than willing to "trample upon the Christian name" and to treat the crucifix with anything but respect. The editorial argued that the Jews had pillaged the Church in France and that their houses are filled with the plunder. The editorial made its construction of the Jew more diabolic by drawing upon the foundation myth. The newspaper thus combined myths about the Pharisee and the ChristKiller with stereotypes about Jewish greed. It stated that "the First Christian of all and the Founder of Christianity [was] put to death, the supreme tragedy of history, by the Jewish people." The editorial concluded with the following question: "If our Jewish brethren still live under the Old Law, the old dispensation, which permitted 'an eye for an eye and a tooth for a tooth' and which made it lawful to 'spoil the Egyptians' and all others who were not Jews, and if they have in certain specific and proved cases shown themselves ready and willing to act on these principles, are we to take it that the mere mention of the fact is evidence of a bigoted and persecuting spirit?" 43 The paper's implicit answer was no.

Charles Diamond reinforced his construction of the Jew with scriptural myth in several other issues of the Catholic Herald. In "The Jew and the World Ferment" (1919) and "Jewry" (1920), in addition to depicting the Jews as gamblers, usurers, parasites, tyrannical bullies, pathetic sycophants and vulgar materialists, Diamond also stated that

the Scribes and Pharisees, the wealthy Israelites, and most of the selfish and hard hearted multitude, sought only power, and glory and pre-eminence for their nation, and led by their rulers, the high priests and the body of the priesthood, they committed the paramount crime of all time.

The "paramount crime of all time" was, of course, the murder of Christ. Diamond suggested that whilst it is "beyond our province even to speculate" as to "how much of what Christians and non-Christians despise in them and denounce is due to what they have endured during the two thousand years of expiation of their unparalleled crime," it was apparent that "their sufferings have not improved them." ${ }^{44}$ Other articles and editorials in the Catholic Herald also combined references to "pharisaically dishonest action," "haters of the Christian name" and "a denial of the Divinity of Christ," with stereotypes of Jewish greed, cowardice, cunning, secrecy, treachery and the myth of a Judeo-Masonic conspiracy. ${ }^{45}$ The paper later complained that Jews had used their influence to have a movie, The King of Kings (1927), modified so that

43 "A Jewish Episode," Notes and Comments, Catholic Herald, 14 November 1914, 2.

44 "The Jew and the World Ferment," Catholic Herald, 14 June 1919, 6 and "Jewry," Catholic Herald, 26 June 1920, 11. The paper later argued that even if their "worst characteristics" can be traced back to their sufferings, "it may be said that they were not persecuted without reason." "An Israelite without Guile," Catholic Herald, 17 August 1929, 4. Even the bars of a prison cell did not prevent Charles Diamond making such claims. "Jewry," signed "C.D.", was published whilst Diamond was serving time in Pentonville.

${ }^{45}$ See for example "The Jewish Question," Catholic Herald, 13 September 1919, 6; "The Jew Danger," Notes and Comments, Catholic Herald, 11 August 1917, 8; "The Jewish Question," Notes and Comments, Catholic Herald, 25 May 1918, 2. 
responsibility for the murder of Christ was confined to the Roman authorities and Caiaphas the High Priest, rather than "the Jewish race as a whole." This was, the Catholic Herald suggested, a gross falsification of the "historical record."

The Tablet also contained articles which referred to the Pharisees and Christ-Killers, though less frequently and with a measure of ambivalence which was absent from the Catholic Herald. For example, an article in 1920 about pogroms in Poland deplored the violence that had been perpetrated against the Jews, but suggested that the problem was partly the result of a "Jewish population which has not assimilated with the Polish people, but perpetuates in itself an archaic polity, curious customs, and as meticulous an observance of its religious ordinances as that of the Pharisees 2,000 years ago. It is a foreign body in the very heart of the State, an Oriental civilization hitherto racially insoluble." ${ }^{\prime 7}$ A review in the Tablet of Herford's What the World Owes to the Pharisees (1919), deprecated the Pharisees in traditional terms - their rejection of Christ and "unworthy conception of God" - suggesting that the "fundamental lie of Pharisaism" was that the "oral tradition" had "Divine authority." This lie, the reviewer continued, separated the Pharisees from the "earlier Old Testament religion." The reviewer concluded by linking the Pharisees with Zionism. He stated that "at the present time, when Zionism is so much in the air, one cannot but feel anxious as to what this Pharisaism, still so dominant among the Jews, is likely to produce, should they acquire political ascendancy in Palestine." ${ }^{48}$

Articles in other English Catholic periodicals linked critiques of Zionism to the rejection and murder of Christ. For example, according to an article in The Month, the periodical of the British Jesuit society, it would be intolerable for the Jews to be "encouraged to overrun" the Holy Land. Donald Attwater, an English Catholic author and journalist, listed a number of reasons, but foremost was the religious. He stated that the Jews were once "the Chosen people," but as a result of their role in Christ's "shameful death," they have become "the accursed people." It is, he suggested, one thing to forgive the Jews (though he pointed out that "neither the Jews as a people, nor their religious leaders, have ever made manifestation of any repentance for their crime"), but forgiveness does not entail a remission of their sentence. The "punishment of this race," Attwater concluded, was "exile from the Promised Land." ${ }^{49}$ The myth of the Christ-Killers once again justified their reduction in status from a chosen people to a wandering witness people. Attwater's narrative about the rejection of Christ was far from atypical of English Catholic constructions of the Zionist Menace. For example, Cardinal Archbishop Bourne, the head of the English Catholic hierarchy from 1903 to 1935, provides another example. He stated in a speech to the Catholic Truth Society in September 1921 that it would be "a gross outrage to the whole sense of Christianity were these sacred lands and the Holy Places which have been wrested from the hands of the

\footnotetext{
46 "Jewish Culpability for the Crucifixion," Notes and Comments, Catholic Herald, 14 January 1928, 8 and "To Please the Jews," Catholic Herald, 21 January 1928, 8.

47 "The Poles and the Jews," Topics of the Day, Tablet, 17 July 1920, 72-73.

48 "Pharisaism," review of What the World Owes to the Pharisees, by R. Travers Herford, Tablet, 27 December 1919, 861. R. Travers Herford was a Unitarian minister and a recognised scholar of rabbinic literature. What the World Owes to the Pharisees (London: George Allen \& Unwin, 1919), contained the text of a lecture he delivered to the Jewish Historical Society of England. The lecture expressed admiration for Judaism as a living religion.

${ }^{49}$ Donald Attwater, "Religious Conditions in Palestine," Month, CXLVIII (October 1926), 354. Attwater was an author and journalist. He worked with Herbert Thurston on the revised edition of Alban Butler's Lives of the Saints (see footnote 82).
} 
infidel by the soldiers of England, to be placed now under the domination of those who have rejected the name of Christ." ${ }^{50}$ Shortly after Bourne's speech, the Catholic Herald explained that Zionism could never be a just aspiration as "the sacrifice of Christ, desired by a people that declared itself responsible for itself and for its children, before God, and before man, constitutes an enormous prescription of right before history, and before civilisation (which be it remembered, is Christian)."

There is only scant evidence upon which to speculate about the effect that these myths about the Pharisee and the Christ-Killer, repeated in sermons and pastoral letters, and incorporated into constructions of the Jew in English Catholic newspapers, had on the socalled "ordinary" lay Catholic. ${ }^{52}$ Though anecdotal, oral testimony has been found that reinforces the suggestion that these myths did have at least some impact on "ordinary" Catholics during the 1910s and 1920s. For example, Mary Brady, a Catholic from Salford, admitted in her recollections that she used to shove and shout at Jews. She stated that "we always thought they killed our Lord you know. Who killed Christ we used to shout." ${ }^{53}$ David Freedman, a correspondent for the Jewish Chronicle whose parents immigrated from Lithuania and Poland, remembered encountering "antisemitism" as a boy. He recalled that this was often from boys his own age, "mostly from Catholic schools," such as St. Chad's. They would shout taunts such as: "dirty Jew, who killed Christ? You killed Christ." ${ }^{54}$ Harold Jenner, an English Catholic from Manchester and former pupil of St. Chad's, stated that he remembered Jewish lads blaspheming Christ and taking His name in vain. According to Jenner,

in those days, the feeling between the Christians and Jews were still present underneath, religious feelings, because if we had an argument, they'd start blaspheming at Christ. Some of them would. And we resented this, the Christian lads.

Jenner also expressed a profound fear of being set upon and killed when entering a Jew's house. He stated that he was "frightened actually, as a child, was always frightened to go in the Jew's house, because I used to hear these tales about Christian children being, you know,

\footnotetext{
${ }^{50}$ Extracts from Bourne's speech, reported in various newspapers, can be found in file Bol/93, Cardinal Bourne Papers: Palestine 1919-1925, Westminster Diocesan Archives, London. A transcript of the speech can be found in "The Zionist Peril," Universe, 7 October 1921, 12.

51 "A Catholic View of Zionism: Why the Jews have no claim to the Holy Land," Catholic Herald, 15 October 1921, 3. Other English Catholic constructions of the Zionist Menace are examined in Mayers, "From 'the Pharisee' to "the Zionist Menace," " ch.5.

52 The use of the term "ordinary" in this study does not indicate the antonym of eccentric, peculiar or special. "Ordinary" is used in a similar way to that employed by Paul Thompson, i.e. as a signifier to indicate the regular individuals whose views have rarely been recorded for posterity. They are the often forgotten actors within myth and history. Paul Thompson, The Edwardians: The Remaking of British Society (1975; repr., Chicago: Academy Chicago Publishers, 1985), 14-15, passim.

${ }_{53}$ Mary Brady, birth date: 1902, transcript (recorded in early 1970s), Interview id: 138, in Paul Thompson and T. Lummis, Family Life and Work Experience Before 1918, 1870-1973 [computer file], 7th Edition, Colchester, Essex: UK Data Archive [distributor], May 2009. SN:2000. The transcripts from this collection can be accessed via the UK Data Archive and Economic and Social Data Service websites: http://www.data-archive.ac.uk/ and http://www. esds.ac.uk (registration may be required). Mary Brady's recollections relate to hanging around streets with "lads" and causing mischief as a teenager, probably during the First World War (but possibly shortly before or after).

${ }^{54}$ David Freeman, birth date: 1901, audio tape (recorded 1977), MJM: J85, Manchester Jewish Museum. As his recollection was of taunts from schoolboys of his own age (probably aged 9-14), the likely date range for these memories was the years leading up to the First World War and possibly into the early years of the war (circa 1910-1915).
} 
you've heard about them, about them being garrotted." ${ }^{55}$ The continued presence in English Catholic discourse of the myths about Jews murdering innocent Christian child is examined in the following section.

\section{The Ritual Murderer and the Sorcerer}

The ritual murder accusation was a medieval development of the Christ-Killer myth. Usually the accusation involved the murder of a Christian child, an innocent martyr and symbolic stand in for Jesus. ${ }^{56}$ In some cases it was even suggested that the child was nailed to a cross in mockery or reenactment of the original crime. The ritual murder myth did not disappear with the conclusion of the Middle Ages. In 1899, as the primary events of the Dreyfus Affair were drawing to a close, another drama was just beginning. In April 1899, in the Czech town of Polna, a young woman, Anežka Hrůzová, was murdered and dumped in a section of the town inhabited by poor Jews. A destitute Jew, Leopold Hilsner, was accused of having murdered Anežka. According to the indictment, the body "had been completely bled" and "the traces of blood found under the body did not correspond to the amount of blood one would expect to find." ${ }^{57}$ The implication was that Anežka was murdered in order to obtain as much of her blood as possible. Scientists and so-called experts in Jewish ritual murder were called in to examine the evidence and express their opinion on whether the murder was committed for religious ritual purposes. The trial of Hilsner became a concern for Jewry as a whole as it was not just Hilsner but Jews in general who were once again accused de facto of practising ritual murder. ${ }^{58}$

In 1898, Herbert Thurston, a well respected Jesuit scholar and prolific author, outlined his views about the likely development of the ritual murder accusation in two works. ${ }^{59} \mathrm{He}$ published an article on ritual murder in the Month and discussed the accusation in a book he edited on Saint Hugh, the Bishop of Lincoln. ${ }^{60}$ The article and book were written a year before the Hilsner Affair. According to Thurston, the article was prompted by the publication of two works which accused the Jews of ritual murder: Les fuifs devant l'Eglise et l'Histoire

${ }^{55}$ Harold Jenner, birth date: circa 1910, audio tape (recorded 1976), MJM: J131, Manchester Jewish Museum. It is difficult to exactly date these recollections. Based on dates mentioned in his testimony and the fact that they seem to include his adolescent childhood fears of entering a Jewish house and his memories as a lad of fighting Jews over their alleged blaspheming of Christ, they probably relate to an interval stretching from circa 1916 to the mid-1920s.

56 The victim was not always a child. In the case of the Hilsner Affair, the victim was a young woman (aged 19).

${ }^{57}$ Records for the Hilsner trial (held at the Central Archives in Prague), cited by František Červinka, "The Hilsner Affair," in Alan Dundes, ed., The Blood Libel Legend (Madison, Wis.: University of Wisconsin Press, 1991), 142.

${ }_{58}$ A good examination of the Hilsner Affair can be found in Červinka, "The Hilsner Affair," 135-161.

${ }^{59}$ Herbert Thurston (1856-1939) was a conservative figure within the Church who had a diverse range of interests, including saints' lives, the ritual murder accusation, Freemasonry, spiritualism and poltergeist phenomena. According to Mary Heimann, Thurston published over a dozen books and nearly 800 articles. He was a respected scholar who was often cited by Catholics and Jews (including Chief Rabbi Hermann Adler), as an authority on the ritual murder accusation. For more on Thurston, see Joseph Crehan, Father Thurston: A memoir with a bibliography of his writings (London: Sheed and Ward, 1952); Mary Heimann, "Herbert Thurston," in H. G. G. Matthew and Brian Harrison, eds., Oxford Dictionary of National Biography, vol. 54 (Oxford: Oxford University Press, 2004), 728-729; Who Was Who, 1929-1940, 1352.

${ }^{60}$ Herbert Thurston, "Anti-Semitism and the Charge of Ritual Murder," Month, XCI (June 1898); Herbert Thurston, The Life of Saint Hugh of Lincoln (London: Burns and Oates, 1898). Saint Hugh, the Bishop of Lincoln, should not be confused with Little Saint Hugh of Lincoln, the "child martyr." 
(1897) by Father Constant and the peculiarly named book by Richard Francis Burton, The Fere, the Gipsy, and El Islam (1898). ${ }^{61}$ Thurston refuted, at length, the charge that the Jews were required by rituals in their religion to murder Christian children and to use their blood for religious purposes. However, he suggested that Jews had, on occasion, murdered innocent Christian children in "odium fidei" and that it would have been "a matter of comparatively little moment" if Father Constant had "regarded these alleged murders as isolated and unauthorised outbreaks of fanaticism, reprobated with horror by the higher and better feeling of educated Israelites." ${ }^{22}$ In his appendix to The Life of Saint Hugh of Lincoln, Thurston referred to an account in the Hebrew chronicles of Rabbi Joseph Ben Joshua Ben Meir, as evidence that "in some cases murders were undoubtedly committed by Jews." ${ }^{63}$ The account in the chronicles does refer to the murder of a Christian child by an insane Jew. According to the account, on the 7th day of Adar in the year 4957 (1197 CE), "a Hebrew, a foolish man, met a Gentile girl and slaughtered her and cast her into the midst of a well, before the face of the sun, for he raved with madness." 64 This was presumably intended by Thurston as evidence that Jews could murder in odium fidei, but the chronicles seem only to depict a spontaneous and motiveless murder by a crazed individual who happened to be Jewish. There is no indication that the girl had been murdered because she was Christian let alone as a consequence of odium fidei. But for a turn of fate the victim may well have been Jewish.

Murder in odium fidei was not the only explanation Thurston provided for the murder of Christian children. The other possible explanation was that the blood was required for Jewish sorcery. In his notes to The Life of Saint Hugh of Lincoln, Thurston stated that he was "inclined . . . to adopt a suggestion," made in a review in the Academy, that "the use of human blood taken from some innocent victim, really did enter into the magic spells of the professors of the black art." ${ }^{165} \mathrm{He}$ found this explanation to be compatible with what St. John Chrysostom had said about "magicians who are said to decoy children to their houses and cut their throats." "Sorcery," Thurston continued, "was practiced amongst the Jews as it was practiced among Christians, and if Christian writers can be trusted, a great deal more so. It is quite possible that some individual Jewish sorcerers may at all periods have combined

\footnotetext{
61 Thurston, "Anti-Semitism and the Charge of Ritual Murder," 562-563. For an examination of Richard Burton and the controversies surrounding The Few, the Gipsy, and El Islam, see Holmes, Anti-Semitism in British Society, 49-62 and Geoffrey Alderman and Colin Holmes, "The Burton Book," Fournal of the Royal Asiatic Society of Great Britain E Ireland, Series 3, 18, no.1 (2008), 1-13. Burton was an explorer, soldier and author. His wife, Isabel Arundell, was a Catholic from an aristocratic family. Arundell claimed that Burton converted to Catholicism and received final rites on his deathbed. However, according to his friends and family, Arundel fabricated the conversion. See Dane Kennedy, The Highly Civilized Man: Richard Burton and the Victorian World (Cambridge, Mass.: Harvard University Press, 2005), 84, 251-259.

62 Thurston, "Anti-Semitism and the Charge of Ritual Murder," 567, 569.

63 Thurston, The Life of Saint Hugh, 609. Thurston went on to observe that "a very vindictive spirit against the Christian breathes in the pages of some of the mediaeval Jewish Chronicles. The tone is quite the tone of Shylock, and we can well conceive that a Jew who thought he could avenge himself with impunity upon some solitary Christian, whether child or adult, might perhaps have felt little scruple in doing so" (610).

${ }^{64}$ The Chronicles of Rabbi foseph Ben Foshua Ben Meir, vol. I, trans. G.H.F. Bialloblotzky (London: Richard Bentley, 1835), 219.

65 Thurston, The Life of Saint Hugh, 286-287; a review in the Academy did suggest that the blood of a murdered innocent was sometimes used in sorcery and that "the charge of ritual murder" may have sprung from the reputation that Jews had for "magic arts" rather than from a hatred of Judaism. "St. William of Norwich," review of The Life and Miracles of St. William of Norwich, by A. Jessopp and M. R. James, eds., Academy, 27 February 1897, 251.

${ }_{66}$ Thurston, The Life of Saint Hugh, 287n1.
} 
this very evil magic with their religious beliefs." According to Thurston, "fudaism as a system [emphasis mine] can certainly not be held responsible for these outrages. None the less, it is very difficult to waive away the evidence of some Jewish complicity in such murders by declaring them all to be the fabrication of popular prejudice." ${ }^{67}$

Each issue of the Tablet contained a section, Topics of the Day, which consisted of an article on a subject of topical interest. On 25 November 1899, the topic of interest was the "ritual murder" charge. The article, written in response to the Hilsner affair, did denounce "the sort of blind and fanatical hatred which demands the persecution of the Jew as though that were part of the duty of a Christian." Nevertheless, whilst ostensibly defending Jews from the ritual murder accusation, the same piece had no problem with what it called "a political and economical conflict" against the Jews, which "in particular countries or districts may be justifiable enough." It suggested that no one is likely to complain if "in this or that country Jewish attempts to squeeze Christians out of a particular industry are met by organized resistance, or if strenuous opposition is offered to an attempt in whatever country, to obtain exclusive control of the Press or the money market. If in parts of France or Austria or Russia the Jews so conduct themselves as to invite economic or political reprisals they have only themselves to blame." The Tablet thus seemed to reject a particularly unsavoury form of medieval hostility, the ritual murder accusation, whilst endorsing social-economic stereotypes about Jewish greed. More importantly, the article's ostensible rejection of the ritual murder accusation was far from unequivocal. Closely following Herbert Thurston's narrative, the article stated that "an entire disbelief in the ritual-murder calumny is quite consistent with the admission that in a few individual cases Christian children may have been murdered by Jews, and even murdered in odium fidei, i.e., because they were Christians." The Tablet reasoned that it was likely that some Jews had murdered innocent Christian children as a result of being "stung to madness" by the "tyrannous oppression under which they laboured." The Tablet cited as an example the same account from the chronicles of Rabbi Joseph Ben Joshua Ben Meir that Thurston had cited the previous year. The Tablet stated that "there are certain forms of homicidal mania in which the very knowledge that Jews were suspected of such deeds would supply just the determining cause for an act of blood if the lunatic chanced to find himself alone with his opportunity." "In such a case," the paper continued, "we could quite believe that this same knowledge might produce the enactment of the very horrors crucifixion, bleeding to death or what not - which were impressed so vividly upon the maniac's brain." The fact that the chronicles by Rabbi Joseph did not specify or imply that the girl was killed because she was a Christian, only that she was a Christian, and nothing suggested the crime was premeditated, involved crucifixion or bleeding to death, seems to have been dismissed as irrelevant detail. The paper concluded that "in any case it is quite easy to conceive how innocent children may sometimes have suffered outrage from the Jews precisely on account of their Christianity, and in such instances they may have been honoured locally as martyrs." ${ }^{\prime 28}$

\footnotetext{
${ }^{67}$ Ibid, 286-287. There is a tradition of Jewish magic, but it contains none of the diabolic sorcery described in these myths. See Joshua Trachtenberg, Fewish Magic and Superstition (1939; repr., Philadelphia: University of Pennsylvania Press, 2004) and Hermann L. Strack, The Few and Human Sacrifice: Human Blood and Jewish Ritual, trans. Henry Blanchamp, 8th ed. (New York: Bloch, [1909]).

68 "The Jews and Ritual Murders," Topics of the Day, Tablet, 25 November 1899, 841.
} 
Another ritual murder accusation began in 1911. Mendel Beilis, a Ukrainian Jew, was accused of murdering a thirteen year old Christian child for ritual purposes in a cave just outside Kiev. He was incarcerated, tortured and interrogated and finally brought to trial in September 1913. Though Eastern Orthodox Christianity was generally hostile to Roman Catholicism, the accusation received the backing of a Roman Catholic priest, Father Pranaitis, and much of the European Catholic press. A number of articles in the Catholic press informed readers in gruesome detail of numerous supposed ritual murders of Christian children by Jews. La Civiltà Cattolica, a Catholic periodical constitutionally connected to the Vatican, published two articles which set out to present "medical opinion" to the effect that "death was brought about in three stages: the boy was stabbed in such a manner that all his blood could be collected, he was tortured, and finally his heart was pierced." This alleged evidence was held to indicate "ritual murder, which only Jews could perpetrate, since it required long experience." 69 As a supposed "expert on Judaism," Father Pranaitis was present during the trial to support the accusation that the Jews murdered Christians in order to obtain their blood for rituals commanded by Jewish law. ${ }^{70}$

The Tablet published an article in its Topics of the Day in response to the Beilis trial. The article vehemently denounced the ritual murder accusation. This time, unlike during the Hilsner Affair, the Tablet did not blame Jews for provoking the incident through attempts to dominate the press or money markets. It did however once again suggest that in the past some Jews had been responsible for the murder of innocent Christian children, not for religious ritual reasons, but as a result of odium fidei. According to the article, even if "little Simon of Trent, Andrew of Rinn, Hugh of Lincoln, and other such child martyrs were canonized, this approval of solemn cultus does not in the least touch the question of ritual murder." The article clarified that "the Church might recognize that these children were put to death by Jews in odium fidei, and therefore truly martyred, without in any way pronouncing that such a practice had its foundation in the ritual of the Jewish religion." A distinction was thus again maintained between ritual murder sanctioned by Judaism and murder by Jews in odium fidei. The article then went on to clarify that in any case none of these child martyrs had received "any proper canonization," though it acknowledged that two of them had "been beatified by Papal decrees." Thurston. According to Thurston, in at least two cases - Simon of Trent and William of Rinn - the child-martyrs were granted "an equipollent beatification," which fell short of "a formal beatification," being only a "conditional approval" rather than an approval based on "the infallible authority of the Church." 72 The theological distinction between "equipollent" and "formal" beatification is not entirely clear, and perhaps more importantly, it is unlikely that the distinction would have been widely understood or appreciated by many "ordinary" Jews and "ordinary" Catholics. Despite the "equipollent" nature of the beatification, Simon

69 "Jewish Trickery and Papal Documents - Apropos of a Recent Trial," Civiltà Cattolica, 11 and 25 April 1914, cited by Charlotte Klein, "Damascus to Kiev: Civiltà Cattolica on Ritual Murder," The Wiener Library Bulletin 27 (1974), 24. For a discussion of the Beilis trial and its reception in Catholic periodicals in Europe, see David I. Kertzer, The Popes Against the Jews: The Vatican's Role in the Rise of Modern Anti-Semitism (New York: Vintage Books, 2002), 227-236.

70 Klein, "Civiltà Cattolica on Ritual Murder," 24.

71 "Cardinal Bourne and the Ritual Murder Accusation," Topics of the Day, Tablet, 25 October 1913, 641.

72 Thurston, "Anti-Semitism and the Charge of Ritual Murder," 569. 
of Trent was nevertheless recorded in the official Roman Catholic Martyrology, where he remained until after the Second Vatican Council.

Herbert Thurston also wrote an article about ritual murder in response to the Beilis trial. ${ }^{73}$ Thurston and the Tablet were once again largely in agreement in terms of the distinction made between religious ritual murder and murder in odium fidei. Whilst Thurston stated that "the immolation of Christian children is in no way sanctioned by the fewish religion as a system [emphasis mine]," he nevertheless reasoned that "considering the incredible and brutal oppression to which the Jews were commonly subjected from the tenth century onwards, it seems extremely likely that in a few isolated instances some half-crazy Israelite may have welcomed the opportunity of venting his spite upon a defenceless Christian child or girl." In other words, murder in odium fidei rather than murder for religious purposes. Thurston again referred to the Hebrew chronicles of Rabbi Joseph Ben Joshua Ben Meir as evidence that at least one such case "did actually happen." As he had in 1898, Thurston also argued that another possible explanation for the emergence of the accusation that Jews murdered Christian children was Jewish Sorcery. He pointed out that during Pesach:

one of the practices which stood almost first in importance in the mind of the less educated Hebrews was the preparation of the Mazzoth or cakes of unleavened bread. These were often preserved with veneration and used medically and, it is probable, magically. Further, we know that magic was much employed among the Jews, and on the other hand the use of blood was so frequent in all magical rites that it is difficult to suppose that the Jews can have escaped the infection. $^{74}$

Thurston concluded, "not that the Jews really made use of Christian blood for liturgical [emphasis mine] purposes, but that the idea of its employment was sufficiently familiar to lead to the belief that in these cakes, which the Jews were known to treat with superstitious reverence, there must be some latent magical power, such as blood might be supposed to impart." Thurston implied that this was how the ritual murder accusation established itself. In an ostensibly balanced but fallacious argument - of the kind that suggests that in any conflict there are faults on both sides - Thurston stated that:

once a belief that the Jews sacrificed Christian children in order to use their blood in the mazzoth, was established and propagated abroad, it would be impossible to eradicate it from the popular mind. Nay, it seems even probable that such beliefs exercised a sort of hypnotic effect upon the victims themselves, in such sort that they also came to think and possibly even to do, in a few isolated cases, the very things of which they were suspected. ${ }^{75}$

In other words, because they were suspected of using Christian blood in sorcery, some of "the victims" of the accusation - i.e. the Jews - started to do so. Referring to the Spanish inquisition trial for the murder of el santo Niño de la Guardia, Thurston concluded that the records indicate that the accusation was not concerned with "ritual sacrifice" (i.e. an accusation against fudaism), but "with the procuring of blood for Jewish magical purposes by taking the life of a Christian child" (i.e. an accusation against "superstitious Jews" who believed in the efficacy of magic). Thurston acknowledged that scholars have argued that "the confessions elicited from the accused were worthless" because of the "diabolical

\footnotetext{
${ }^{73}$ Herbert Thurston, "The Ritual Murder Trial at Kieff," Month, CXXII (November 1913).

${ }^{74}$ Ibid, 511-513.

75 Ibid, 512.
} 
ingenuity of their torturers." Thurston however concluded that this was not the case. He stated that "after a careful study of the records, we have come round to the opinion of $\mathrm{Mr}$. Rafael Sabatini in his recently-published volume on Torquemada. We believe that in this particular trial the admissions made in the examinations before the Inquisition were faithfully reported, and in substance, accurate as to the facts." 76

A similar equivocation can be detected in a speech by Father Joseph Bampton, a Jesuit colleague and friend of Herbert Thurston, at a meeting about the ritual murder accusation organised by the English Zionist Federation in October 1913. ${ }^{77}$ Bampton's speech was quoted in the Fewish Chronicle and the Tablet. Bampton stated that before coming to the meeting he had consulted with "an expert in these matters, my friend Father Thurston," and that he thus felt "fortified by his authority." Bampton expressed "complete incredulity" at the "ritual murder charge," but like Thurston, he seemed to narrowly define it as the accusation that Jews murder Christians in compliance with their religious rites. Whilst Bampton acknowledged that "no such rite exists," he nevertheless stated that "there can be no question that at different times and in different places throughout the Christian era Christian children have been put to death by members of the Jewish race out of hatred for Christianity, and that such children are venerated as child martyrs, and that veneration is approved by the Catholic Church." Bampton implied that these children were murdered not by orthodox Jews, but by "a parcel of fanatics" that happened to be Jewish. This should not, he suggested, be taken as "evidence of any precept of the Jewish law or any accordance with any Jewish rite." He stated, presumably in mitigation, that "I suppose Jews have murdered Christians and Christians have murdered Jews at different times, but because Christians have murdered Jews, we have never heard of any charges of ritual murder brought against Christians." ${ }^{.8}$ According to the account in the Tablet, Bampton clarified that

we must remember that the accusation we are concerned with and the one we are here to protest against is a charge of ritual murder, i.e., of murder of Christians by Jews, committed in compliance with some precept or ritual observance of the fewish law [emphasis mine]. We are not here to declare that no Christians, whether children or adults, have ever been murdered by Jews out of hatred to the Christian faith, any more than we are here to declare that no Jews have ever been murdered by Christians out of hatred to the Jewish faith. ${ }^{79}$

Bampton's equivocal defence, as reported in both newspapers, sounds balanced on the surface.$^{80}$ However, it is problematic for at least three reasons. Firstly, he suggested that Jews

\footnotetext{
${ }^{76}$ Ibid, 512-513. Rafael Sabatini (1875-1950) argued that the child was murdered, not as "an instance of Jewish ritual murder," but for the purpose of extracting his heart to use in a Jewish enchantment. The crucifixion was unnecessary to the enchantment, but was nevertheless done, Sabatini suggested, merely "in derision and vituperation of the Passion of Jesus Christ." Sabatini therefore argued that the child was murdered both in odium fidei and for magical purposes. Rafael Sabatini, Torquemada and the Spanish Inquisition (1913; repr., Thirsk, North Yorkshire: House of Stratus, 2001), 254. Sabatini was a prolific author of novels, short stories and non-fiction. His mother was English, his father Italian, and he spent most of his life in England.

${ }_{77}$ Joseph Bampton (1854-1933?) was the rector of Farm Street Church (the home of the British Jesuits) and Beaumont College. See Catholic Who's Who \& Year Book, 1933 (London: Burns Oates \& Washbourne, 1933), 16.

78 "Beilis: Great Protest Meeting in London," Jewish Chronicle, 31 October 1913, 29.

79 "The Ritual Murder Charge: Protest Meeting in London," Tablet, 1 November 1913, 692.

${ }^{80}$ Bampton's formulation was of a type summed up by Anthony Julius (whilst discussing anti-Jewish passages by G. K. Chesterton): "a nicely balanced formulation, one that appeals to a kind of fair-to-both-sides, 'six of one, half a dozen of the other', sentiment." Julius, Trials of the Diaspora, 422.
} 
had murdered Christian children and Christians had murdered Jews, but he never suggested that Jewish children had been murdered, let alone in the diabolic manner traditionally associated with accusations of murder in odium fidei (i.e. with crucifixion or blood draining). Secondly, the Christian children, allegedly murdered out of "hatred for Christianity," became the subject of veneration as Bampton acknowledged, and thus acquired theological significance. These were therefore not murders, or accusations of murders, in a mundane or conventional sense. The medieval narratives which arose about these "murders" helped to reinforce the resilient image of the diabolic Jew in traditional Christian myths. Thirdly, Bampton made the relationship between Jews and Christians sound very bilateral, with Jews oppressing Christians as much as Christians oppressed Jews, but this does not correspond to the power dynamic that existed in Christian Europe.

Whereas the Rome based Catholic newspaper, La Civiltà Cattolica, produced unequivocal articles cataloguing cases of ritual murder, arguing that the Jews not only killed innocent Christian children out of odium fidei but also because they needed to consume their blood to satisfy religious commandments, ${ }^{81}$ it seems plausible that the equivocation of Thurston and Bampton reflected a genuine desire to defend Judaism (rather than all Jews) from the charge of ritual murder. No doubt they felt they had to develop a defence which on the one hand demonstrated religious tolerance and on the other hand did not challenge already existing child-martyr cults. It is possible that they would have been less equivocal if the cults and shrines of the child martyr saints had not existed. On the other hand, Thurston felt little compunction about using the ritual murder accusation to balance out certain Protestant anti-Catholic myths in a way that suggests he did believe the accusation had supporting evidence. He stated in an article published in 1894 (and republished in 1902), that "the evidence for the Jewish murder of Christian children is simply overwhelming beside any evidence which ever has been adduced or is ever likely to be adduced for the walling-up of nuns. In the former case we have at least full details of names, place, and time, we have judicial inquiries, we have the record of contemporary documents, we have the testimony of witnesses on oath." 82

Significantly, the fewish Chronicle expressed its appreciation for many of these equivocal refutations of the ritual murder charge. The Jewish Chronicle lavished praise on Father Thurston's June 1898 article for its "enlightened effort to nail the abominable falsehoods that pass current amongst anti-Jews to the counter." It neglected to mention that Thurston had suggested that some Jews had murdered innocent Christian children in odium fidei. ${ }^{83}$ The fewish Chronicle also applauded - and very selectively quoted from - the article which

\footnotetext{
${ }^{81}$ See Klein, "Civiltà Cattolica on Ritual Murder."

${ }^{82}$ Herbert Thurston, "Mr. Rider Haggard and the Immuring of Nuns," Month, LXXX (January 1894), 15. This was republished in Herbert Thurston, "The Myth of the Walled-up Nun," in Publications of the Catholic Truth Society, XXI (London: Catholic Truth Society, 1902), 2-3. In the 1920s and 1930s, Thurston led a project to revise Alban Butler's Lives of the Saints. The revised entries for Little St Hugh of Lincoln, St Simon of Trent and St William of Norwich equivocally defended the Jews, suggesting that Jewish "maniacs" or "necromancers" may have killed Christian children, possibly to satisfy "some magical rite" or out of "hatred for their religion," and possibly involving "crucifixion and mockery of the passion of Christ," but not as part of any "Jewish ritual" or "general practice." Herbert Thurston and Norah Leeson, eds., The Lives of the Saints, 2nd ed., vol. III (London, Burns Oates \& Washbourne, 1931), 388-389; Herbert Thurston and Donald Attwater, eds., The Lives of the Saints, 2nd ed., vol. VI (London, Burns Oates \& Washbourne, 1931), 208.

83 "A Catholic Protest against Anti-Semitism," Fewish Chronicle, 17 June 1898, 17-18.
} 
appeared in the Tablet in November $1899 .{ }^{84}$ It similarly praised the speech by Father Bampton in October 1913. ${ }^{85}$ Chief Rabbi Hermann Adler wrote a letter to Thurston on 10 June 1898 to thank him for his article. ${ }^{86} \mathrm{He}$ also recommended Thurston's "scholarly article" in a letter to the Tablet. ${ }^{87}$ Israel Abrahams seems to have been the only English Jew who noticed that Thurston only "half-heartedly" defended Jews from the charge of ritual murder. ${ }^{88}$ Despite the thanks that the equivocal defences by Thurston, Bampton and the Tablet elicited from the Fewish Chronicle and the Chief Rabbi, only a thin line separated them from the more overtly polemical uses of the ritual murder myth by other English Catholics, such as Montague Summers and the Chesterton brothers.

Cecil Chesterton, like his close friend Hilaire Belloc and his brother G. K. Chesterton, frequently discussed the Jew in his newspaper articles. ${ }^{89}$ Cecil drew upon the myth of the ritual murder as part of his wider construction of Jewish villainy and foreignness. In 1914, in the New Witness, in response to the Beilis Affair, he characterised Russian pogroms as something horrible, but also something to be understood as part of an ongoing "bitter historic quarrel between [Israel Zangwill's] own people and the people of Russia." The evidence, he argued, points to a "savage religious and racial quarrel." He suggested that it was sometimes the "naturally kindly" Russians who were "led to perpetrate the atrocities," and sometimes it was the "equally embittered" Jews, who, "when they got a chance of retaliating, would be equally savage." Referring to the Beilis affair, he stated that:

An impartial observer, unconnected with either nation, may reasonably inquire why, if we are asked to believe Russians do abominable things to Jewish children, we should at the same time be

84 "The English Catholic Press and the Blood Accusation," Fewish Chronicle, 1 December 1899, 12 and "English Catholics and the Blood Accusation," Jewish Chronicle, 1 December 1899, 16-17.

${ }_{85}$ According to the correspondent for the Fewish Chronicle, Father Bampton "held the audience spell-bound while he explained the consistent attitude of denunciation of his church of the foul and monstrous charge which had from time to time been brought against the Jewish people" (26). The correspondent did not mention the equivocation in Bampton's speech. However, whilst Bampton's speech implied that Jewish "fanatics" had murdered Christian children, the speeches by the president of the English Zionist Federation, Sir Francis Montefiore, and the Chief Rabbi, Joseph Hertz, both denied the charge that "obscure sects" of uncivilised Jews engaged in such murders (28, 30). Francis Montefiore pointed out that this charge was in some ways more insidious, as whilst the ritual murder charge was "bound to fail" when levelled against "the Jews generally," it may sound believable when levelled against an "obscure sect" (28). "Beilis: Great Protest Meeting in London," Fewish Chronicle, 31 October 1913, 26, $28,30$.

${ }^{86}$ Hermann Adler to Herbert Thurston, 10 June 1898, in Crehan, Father Thurston, 102.

${ }^{87}$ Hermann Adler, Letters to the Editor, Tablet, 24 February 1900, 295.

${ }^{88}$ Israel Abrahams, "Saint Hugh of Lincoln," fewish Chronicle, 12 August 1898, 17.

${ }^{89}$ Cecil Chesterton, G. K. Chesterton and Hilaire Belloc were all involved in the New Witness newspaper and shared similar social and political views. Cecil Chesterton (1879-1918) converted to Roman Catholicism in 1912, ten years prior to G. K. Chesterton. Cecil Chesterton was one of the main agitators during the Marconi Affair. G. K. Chesterton (1874-1936) was a journalist and prolific author of poems, novels, short stories, travel books and social criticism. He also wrote books exploring philosophical and theological ideas. Caricatures and stereotypes of Jews regularly appeared in his fictional and non-fictional works. Throughout his early adult life, Chesterton was an Anglo-Catholic (a form of Anglicanism which accepted aspects of Roman Catholic liturgy, theology and practice, without embracing the authority of the Pope). Chesterton may not have been a de jure Roman Catholic before his formal conversion in 1922, but his worldview had long been Roman Catholic. Hilaire Belloc (1870-1953) was born in France but most of his childhood was spent in West Sussex. Belloc's father was French and his mother was English. After completing his education at John Henry Newman's Oratory School in Birmingham, Belloc served in the French army before returning to England to study at Balliol College. He naturalised as a British citizen in 1902. Belloc was MP for Salford from 1906 to 1910 . He wrote a number of critiques about the English political system, the decline of European civilisation following the Reformation, the Jews, the Freemasons and Bolshevism. He also wrote a number of novels in which these themes were often explored. 
asked to regard it as incredible ... that Jews do abominable things to Russian children - at Kieff, for instance.

Cecil Chesterton also revived the host desecration myth. He stated that "the Jews may or may not have insulted the Host, as was alleged. I do not know." "But," he continued, "I do know that they wanted to; because I know what a religion means, and therefore what a religious quarrel means." ${ }^{90}$ This insight into what he considered expected conduct in a "religious quarrel" - and his belief that Jews would care about the destruction of host wafers, which have a place in Christian myths but hold no significance in Judaism - is revealing of his polemical mind-set. Israel Zangwill, a prominent Anglo-Jewish author and playwright, countered Cecil Chesterton's accusation by stating that following his logic we should have to accept that if hooligans throttle Quakers then Quakers must also be throttling hooligans. Furthermore, he argued, it is incredible that Jews would murder a Christian child for ritual purposes when no such rite has ever been found in Jewish texts. ${ }^{91}$ In response Cecil Chesterton stated that "as to 'ritual murder', Mr. Zangwill, of course, knows that no sane man has ever suggested that [ritual murder] was a 'rite' of the Jewish Church any more than pogroms are rites of the Greek Orthodox Church." He then proceeded to clarify that what he and others had suggested, is that "there may be ferocious secret societies among the Russian Jews," and that "such societies may sanctify very horrible revenges with a religious ritual.",92 Cecil's brother, G. K. Chesterton, also incorporated the ritual murder myth into his construction of the Jew. He argued that members of the "Hebrew race" had engaged in the murder of children. In the Everlasting Man (1925), he stated that:

The Hebrew prophets were perpetually protesting against the Hebrew race relapsing into idolatry that involved such a war upon children; and it is probable enough that this abominable apostasy from the God of Israel has occasionally appeared in Israel since, in the form of what is called ritual murder; not of course of any representative of the religion of Judaism, but by individual and irresponsible diabolists who did happen to be Jews. ${ }^{93}$

Herbert Thurston was not alone in suggesting that one explanation for the ritual murder accusation was Jewish sorcery. Montague Summers, an idiosyncratic Catholic clergyman

\footnotetext{
${ }^{90}$ Cecil Chesterton, "Israel and 'The Melting Pot,'” New Witness, 5 March 1914, 566-567; Cecil Chesterton, "A Letter from Mr. Zangwill," New Witness, 12 March 1914, 593.

${ }^{91}$ Israel Zangwill to the editor of the New Witness (Cecil Chesterton), in Cecil Chesterton, "A Letter from Mr. Zangwill," 593.

${ }_{92}$ Cecil Chesterton, "A Letter from Mr. Zangwill," 594.

${ }_{93}$ G. K. Chesterton, The Everlasting Man (London: Hodder and Stoughton, [1925]), 136. Whilst this seems to have been the only occasion that Chesterton claimed that "diabolist" Jews engaged in ritual murder, constructions of the diabolic Jew did also appear in his fiction. For example, in "The Duel of Dr. Hirsch" (1914), the Jew, Dr. Hirsch/Colonel Dubosc, is modelled on a diabolic composite of Judas Iscariot, Captain Dreyfus, Dr. Jekyll and Mr. Hyde. Hirsch sets up a second Dreyfus affair, playing simultaneously the role of the accused villain and the accusing hero. Hirsch succeeds in his complex scheme to be vilified, vindicated and heralded as a hero. At the conclusion of the story, he is seen by Father Brown's assistant, half way through his metamorphosis from Colonel Dubosc to Dr. Hirsch. His face with its "framework of rank red hair" looked like "Judas laughing horribly and surrounded by capering flames of hell." G. K. Chesterton, "The Duel of Dr. Hirsch," in G. K. Chesterton, The Complete Father Brown Stories (1914; repr., London: Wordsworth Classics, 2006), 224. This short story is examined in Cheyette, Constructions of "the Jew" in English Literature and Society, 192-193. The final image of Hirsch/Dubosc is reminiscent of a "devil-worshipper" that Chesterton claimed he once knew, with "long, ironical face . . and red hair," and when seen in the light of the bonfire, "his long chin and high cheek-bones were lit up infernally from underneath; so that he looked like a fiend staring down into the flaming pit." G. K. Chesterton, "The Diabolist," Daily Neres, 9 November 1907,6 .
} 
and once a popular author with interests in witchcraft and demonology, provides another example, though unlike Herbert Thurston, Summers made no pretence of even equivocally defending Jews. ${ }^{94}$ He claimed in The History of Witchcraft and Demonology (1926) that the Jews were persecuted during the Middle Ages not because of their religion, but as a result of their "practice of the dark and hideous traditions of Hebrew magic." According to Summers, "closely connected with these ancient sorceries" were a whole series of "ritual murders" committed by "certain rabbis." "In many cases," he concluded, "the evidence is quite conclusive that the body, and especially the blood of the victim, was used for magical purposes." Cohn stated in 1975 that some of the basic contentions in The History of Witchcraft "continue to be taken seriously by some historians down to the present day." 96 One might hope that the assertions in The History of Witchcraft are no longer taken too seriously, but what can be said with some confidence is that there is still a market for the volume. It has been republished many times since 1926 and was recently reissued by Routledge in November 2009.97

\section{The Fewish Antichrist}

The Christian foundation myth, being protean, evolved over time, as did the role of the Jews within it. Paul's second epistle to the community at Thessalonica warned that the second coming of Christ will be preceded by the appearance of "the man of sin" who will work false miracles and exalt himself over God, setting himself up in God's Temple, all in accordance with the plans of Satan (2 Thess 2:1-17). The "man of sin" was subsequently linked to the Antichrist mentioned in John's first and second Epistle (1 John 2:18-22, 4:3, 2 John 1:7). Various diabolic figures from the Book of Daniel and the Book of Revelation have also been interpreted as relating to the Antichrist. These allusions to a diabolic character were fleshed out over time. It was perhaps inevitable that the Jews, already key villains in Christian myths, and the Antichrist, would coalesce into a new mythological role, "the Jewish Antichrist," whose arrival would mark the beginning of an apocalyptic conflict. The early Church Fathers increasingly linked the prophesied Antichrist with the Jews. ${ }^{98}$ The Antichrist,

\footnotetext{
${ }^{94}$ Montague Summers (1880-1948) was an ordained deacon in the Church of England who converted to Catholicism in July 1909. He was granted the clerical tonsure in December 1910. He deliberately cultivated a reputation as an eccentric and he was a familiar sight in London and Oxford, wearing a soutane, buckled shoes and shovel hat. He had a particular interest in the occult and witchcraft. Robertson Davies, "Montague Summers," in Matthew and Harrison, Oxford Dictionary of National Biography, vol. 53, 320-321. Summers is mentioned as a factor in the resurgence of the ritual murder accusation by Julius, Trials of the Diaspora, 439; Colin Holmes, "The Ritual Murder Accusation in Britain," Ethnic and Racial Studies, 4, no. 3 (July 1981), 275; Trachtenberg, The Devil and the Jewes, 155; and Norman Cohn, Europe's Inner Demons: The Demonisation of Christians in Medieval Christendom (1975; repr., London, Pimlico, 2005), 160. Cohn observed that Summers was "a Roman Catholic of a kind now almost extinct - obsessed by thoughts of the Devil, perpetually ferreting out Satan's servants whether in past epochs or in the contemporary world." (160).

${ }_{95}$ Montague Summers, The History of Witchcraft and Demonology (London: Kegan Paul, Trench, Trubner, 1926), 194-196.

96 Cohn, Europe's Inner Demons, 160.

97 See http://www.routledge.com/books/details/9780415568746/ (accessed 13 April 2012).

98 The earliest explicit reference to a Jewish Antichrist in the texts of the Church Fathers seems to have been by St. Irenaeus in the 2nd century. In Adversus Haereses (Against Heresies), Irenaeus concluded that the Antichrist will one day come and he will be from the tribe of Dan. See Irenaeus, Five Books of S. Irenaeus, Bishop of Lyons: Against Heresies, trans. John Keble (Oxford: James Parker, 1872), bk. V, chap. XXX, 519-522.
} 
they declared, would be a Jew and would be worshipped by the Jews as their messiah. ${ }^{99}$ According to Norman Cohn, these constructions of the Jew were "revived and integrated into a whole new demonology" during the Middle Ages. Cohn stated that "from the time of the first crusade onwards Jews were presented as children of the Devil, agents employed by Satan for the express purpose of combating Christianity." 100

During the Middle Ages, Satan and a host of demons were pivotal to explanations of important world events. The Antichrist was regarded as an authentic manifestation of evil, who would lead Satan's forces in a war against the followers of Christ shortly before the Second Coming. The Antichrist was thus intertwined with millenarian expectations of the establishment of the Kingdom of God on Earth. As Trachtenberg observes, in the modern era the Antichrist myth may be "easily dismissed as pure fantasy, merely another of the fabulous motifs that entertained the Middle Ages, without exerting any momentous influence upon the thought and action of the common people." However, as Trachtenberg rightly concludes, the Antichrist was considered "a terrifying reality." 101 The arrival of the Antichrist, as Cohn observed, was considered no mere "phantasy about some remote and indefinite future but a prophecy which was infallible and which at almost any given moment was felt to be on the point of fulfilment." 102 Momentous events, such as "the Turks" advancing into the heart of Europe, the Crusades and the Black Death, were interpreted as signs that the Antichrist or Lawless One was in the world.

For some English Catholics in the late nineteenth- and early twentieth-century, Satan and the Antichrist were more than just narrative artefacts from the Middle Ages. Satan and a host of malign spirits were often described as very real agents responsible for a number of the world's woes and fighting the Church for the souls of men. ${ }^{103}$ The Antichrist was invoked by English Catholic newspapers to explain modern developments, such as the collapse of the Papal States, the massacre of Catholics in Mexico and the rise of Bolshevism. The Antichrist was a resilient theme which was by no means dependent on the presence of the Jew. For example, a popular English Catholic newspaper, the Universe, contained two articles in 1914, one in June and the other in November, which revolved around the Antichrist. According to the June article, the arrival of the Lawless One was part of "the history of the everlasting unseen war of spiritual forces, repeating itself with cyclic fury." The paper suggested that "the forces of evil have ranged themselves in most furious onslaught on humanity." Every degenerate anti-Christian and anti-Church impulse of modern society, such as the vulgarisation of speech and deterioration of manners, "unbridled sensuous indulgence" and "resurgent women, who renounce the sacredness of home" and the eruption of hatred and the anti-Christian revolution, can be traced, the article suggested, to the spirit of "lawlessness" and the "dethronement of Christ in the hearts of men, and the

\footnotetext{
${ }_{99}$ See Norman Cohn, Warrant for Genocide (1967; repr., London: Serif, 1996), 48.

${ }^{100} \mathrm{Ibid}, 26$. For a good introduction to the Jewish Antichrist myth, see Trachtenberg, The Devil and the Fews, 3243. For an introduction to millenarian expectations of a battle between the forces of Christ and the Antichrist, see Norman Cohn, The Pursuit of the Millennium (1957; repr., London: Pimlico, 1993).

101 Trachtenberg, The Devil and the Fews, 37-38.

102 Cohn, The Pursuit of the Millennium, 35.

${ }^{103}$ The following are just some examples of articles relating to Satan and Devil worship in English Catholic newspapers: "Black Magic: Horrors of Devil-Worship," Catholic Herald, 17 January 1914, 7; "Satanic Spiritism," Universe, 27 April 1917, 3; Hugh Pope, "The European War and Spiritualism," Universe, 5 April 1917-27 April 1917; "What of Spiritualism - Is it Satanism?," Catholic Times, 18 January 1929, 11.
} 
erection of the throne of Satan." The article reasoned that the "cultus of evil spirits" and an increasing interest in "fortune-telling," "crystal-gazing," "necromancy," "astrology" and "overt devil-worship" were "portents of evil," "symptoms of minds diseased" and evidence that the "Lawless One is abroad." 104 Referring to anti-Catholic atrocities occurring in Mexico, the destruction of Catholic property, the desecration of alters and sacred vestments and the massacring of the sick and wounded, the November article argued that the "spirit of Antichrist is, indeed, ranging the earth." According to the article, the malice in Mexico and elsewhere reveals a hatred of God "beyond the power and limits of mere human malice." The article stated that "those who believe in the presence of unseen forces that surround us and enter the currents of human action, are compelled to see in all these revelations the manifestation of the 'the mystery of iniquity.'" "The 'Man of Sin' openly proclaims himself," the article reasoned, and "the spirit of Antichrist in its hideous malignity unmasks itself in Mexico, as it did in Portugal and in France." 105 This piece prompted a number of letters to the Universe which debated the nature of the Antichrist. ${ }^{106}$ The Tablet was also not immune to this millenarian vocabulary. An editorial in the paper observed that whilst "Modernists will smile at us as hopelessly old-fashioned, we do not hesitate to say that the prevailing evils are not wholly to be explained as by-products of the Great War. There is something Satanic about it all." The paper concluded that the "present struggle between Christ and AntiChrist" had been accurately prophesised by Cardinal Newman and that Catholics should pray that the "Prince of the Heavenly Host will be with us in this day of battle."107

Whilst English Catholic narratives about the Antichrist did not necessitate the presence of the Jew, the two did on occasion firmly coalesce. Canon William Barry, a senior cleric within the English Catholic hierarchy and a prolific author, developed a complex construction of the Jew which drew upon stereotypes of Jewish usury, capitalism, Bolshevism and secrecy and myths about a Judeo-Masonic conspiracy. ${ }^{108}$ Barry also incorporated the myth of the Jewish Antichrist into this construction as a core component. The Jewish Antichrist myth served much the same function as the Christ-Killer narrative. It was used as a justification for treating Jews as a menace to Christian civilisation that needed to be kept under control.

Barry's incorporation of the Jewish Antichrist into his construction of the Jew was influenced by Henry Manning's formulation of this traditional narrative. Manning also had a profound influence on other English Catholics such as Hilaire Belloc and Cardinal Vaughan. It is thus instructive to first examine Manning's representation of the Jewish Antichrist even though it was constructed a little early to be considered the late nineteenth

104 "The Lawless One," Universe, 19 June 1914, 8.

105 "Antichrist in Mexico," Universe, 20 November 1914, 6.

106 "Antichrist," Letters to the Editor, Universe: 4 December 1914, 4; 11 December 1914, 4; 18 December 1914, 4; 24 December 1914, 4.

${ }^{107}$ News and Notes, Tablet, 28 September 1929, 397.

${ }^{108}$ Dr William Barry (1849-1930), Canon of Birmingham archdiocese, was a well connected figure within the Church. He was a scholar, theologian, prolific writer and a supporter of Ultramontanism. His parents were Irish. Barry wrote numerous articles for the Catholic Times and was described by the paper as "a soldier of Christ." He was the recipient of the "Holy Father's congratulations and blessings on his efforts as a priest and public writer" and honoured as a Protonary Apostolic of the Roman Court. See Catholic Who's Who \& Year Book, 1928 (London: Burns Oates \& Washbourne, 1928), 21-22 and "Mgr. Canon Barry's Retirement," Catholic Times, 3 August 1928, 2. According to Ehret, he was respected by senior ecclesiastics including Cardinal Bourne and Archbishop McIntyre, both of whom encouraged his work. Ehret, "Catholics and Antisemitism," 154. For more on William Barry, see Sheridan Gilley, "Father William Barry: Priest and Novelist," Recusant History, 24, no.4 (October 1999). 
century. Manning discussed the arrival of the Antichrist in a series of lectures delivered in 1861. These were published in 1862, a time when most of the Papal States had been seized by the Risorgimento. ${ }^{109}$ The collapse of the Papal States was often blamed on Jews and Freemasons. At this time Father Manning, who had converted to Catholicism in 1850 and was advancing rapidly within the Church, was it seems quite willing to accept the Jew as a scapegoat for this catastrophe. Whilst he later adopted more positive stereotypes of the Jews, he nevertheless republished these lectures verbatim with a new preface in 1880. By this time he was Cardinal Archbishop of Westminster and thus the official head of the English Catholic hierarchy. ${ }^{110}$ Manning explained in these lectures that whilst it may "run counter to the popular spirit of these times," for someone who believes in revelation, it is inconsistent to try to explain contemporary history without taking prophecy and the Divine will into consideration. ${ }^{111}$ "The theory, that politics and religion have different spheres," Manning argued, "is an illusion and a snare." 112 Manning stated that it is a "master-stroke of deceit" to attempt to allay fears by dismissing the Antichrist as a mere "spirit or system" of the times rather than "a person." The "prophecies of Revelation," he explained, describe the Antichrist with "the attributes of a person" and "to deny the personality of Antichrist, is therefore to deny the plain testimony of Holy Scripture." 113 Manning informed his audience that the "[Church] Fathers believed that Antichrist will be of the Jewish race." He stated that such was the belief of "St. Irenaeus," "St. Jerome," "St. Hippolytus," "St. Ambrose" and "many others." He concluded that they were probably correct considering that "the Antichrist will come to deceive the Jews, according to the prophecy of our Lord." 114 Manning explained that whilst the Antichrist will at first pretend to believe in the Jewish laws, he will only do this "in dissimulation." Afterwards he will "reject the law of Moses, and will deny the true God who gave it." The Antichrist will be received by the Jews because they are still awaiting the coming of their messiah and "they have prepared themselves for delusion by crucifying the true Messias." It is not "difficult to understand how those who have lost the true and divine idea of the Messias may accept a false," Manning stated, and that "being dazzled by the greatness of political and military successes," they will pay that honour to the Antichrist that "Christians pay to the true Messias." The Antichrist, Manning argued, will be "a temporal deliverer, the restorer of their temporal power; or, in other words, a political and military prince." 115 Manning explained that the only thing that will hinder the arrival of the Antichrist is "Christendom and its head," as "the lawless one" has no "antagonist on earth more direct than the Vicar of Jesus Christ." "116

\footnotetext{
109 Henry Manning, The Temporal Power of the Vicar of Fesus Christ, 2nd ed. (London: Burns \& Lambert, 1862).

${ }_{110}$ After graduating from Oxford with first class honours, Manning (1808-1892) first turned to the Colonial Office for employment before deciding that his vocation lay within the Anglican Church. At first he was a committed Anglican, believing that the Church of England was a branch of the Catholic Church. He later decided that this was not the case and converted to Roman Catholicism in 1851. He rose rapidly through the ranks and was elected Archbishop in 1865 and Cardinal in 1875. Manning was a fervent advocate of Ultramontanism and one of the strongest supporters of papal infallibility during the First Vatican Council.

111 Manning, The Temporal Power, 81.

112 Ibid, 102-103.

113 Ibid, 103-104.

114 Ibid, 105-106.

115 Ibid, 107-108, 112-113.

116 Ibid, 127-128.
} 
Cardinal Manning later expressed admiration for the communal solidarity and organisation of the Jews and raised his voice in defence of Jews on a number of occasions. In an address delivered at a meeting organised by the Lord Mayor of London in 1882, Manning condemned the persecution of Jews in Russia and praised the virtues of Jews in England, France and Germany. Manning asked, "for uprightness, for refinement, for generosity, for charity, for all the graces and virtues that adorn humanity where will be found examples brighter or more true of human excellence than in this Hebrew race"? ${ }^{117}$ Manning lamented the ritual murder accusations, on which subject he corresponded with Chief Rabbi Herman Adler. He was presented with an illuminated address of thanks by the Chief Rabbi and frequently praised by the Fewish Chronicle. Considering the support that Manning provided the Jewish community in the late nineteenth century, it seems strange that he embraced the Jewish Antichrist myth. In this, Manning followed a not uncommon precedent of excoriating the Jew theologically whilst defending Jews socially. After addressing the question of papal infallibility at the First Vatican Council (1868-1870), Manning became less concerned with theological problems and more focused on the social needs of English Catholics. ${ }^{118}$ This change in focus may explain why his acceptance of the Jewish Antichrist myth was subsequently accompanied by an admiration for Jewish communal organisation. For example, he argued that Jews were doing more for their working girls in the East End of London than Catholics were doing for their own struggling poor. ${ }^{119} \mathrm{He}$ also stated, in a letter written to Sir John Simon in 1890, that the Jews are:

a race with a sacred history of nearly four thousand years; at present without a parallel, dispersed in all lands, with an imperishable personal identity, isolated and changeless, greatly afflicted, without home or fatherland; visibly reserved for a future of signal mercy. . . . any man who does not believe in their future must be a careless reader, not only of the old Jewish Scriptures, but even of our own. ${ }^{120}$

Though this portrayal was not overtly negative like constructions of the Jewish Antichrist, it was still an essentialistic and patronising image of a "changeless" mythologized people.

In a four part article published in the Catholic Times in 1920, ${ }^{121}$ William Barry, like Manning before him, expressed his fears that "the end of an age is upon us, and we are not ready." 122 Like Manning, Barry had a "highly coloured vision of history as the unfolding of the will of God." 123 Barry argued that the "long-drawn anti-Christian movement, centuries old," was poised to defeat Christendom having been "quickened by victory after victory." Barry cited Manning at length and blended his own impressions of the arrival of the Jewish Antichrist with those found in Manning's lectures. Closely following Manning's lectures, Barry also asserted that the Antichrist would be Jewish, an arch-medium, a protector of the Jews who would be worshipped by them as their messiah. Barry stated that it is clear from "St. Paul's

\footnotetext{
117 Transcript of speech by Cardinal Manning, in "Persecution of the Jews in Russia," Times, 2 February 1882, 4. My thanks to Dr Peter Nockles for bringing this to my attention.

${ }_{118}$ See J. Derek Holmes, More Roman than Rome: English Catholicism in the Nineteenth Century (London: Burns \& Oates, 1978), 158.

${ }_{119}$ See Shane Leslie, Henry Edward Manning: His Life and Labours (London: Burns Oates \& Washbourne, 1921), 485.

${ }^{120}$ Cardinal Manning to Sir John Simon, 8 December 1890, cited by Leslie, Henry Edward Manning, 485-486.

${ }^{121}$ William Barry, "Sign of the Times I-IV," Catholic Times, 30 October 1920-20 November 1920.

122 William Barry, "Sign of the Times I," Catholic Times, 30 October 1920, 7.

${ }^{123}$ Gilley, "Father William Barry," 525.
} 
doctrine" and what "St. John and the Fathers have left us concerning the Antichrist," that the question of the Jew's role in the fate of Europe will be, as Manning argued, the "most vital and most decisive of all." ${ }^{24}$ Manning was concerned that it might "appear strange to attach much importance to any event the sphere of which seems to be the Jewish race."125 The state of affairs in the present day, Barry suggested, should overcome any such temptation to dismiss Manning's prophetic warning. The years, he argued, are "bringing Antichrist nearer," and many voices other than Manning's now announce his approach "to the City of God." "All the portents," Barry concluded, "have been fulfilled in Russia, not to say elsewhere." 126

According to Barry and Manning, there are only two agencies in the history of the modern world that are independent of and more powerful than any of the nations, and these are mutually antagonistic: "the Jewish people" and "the universal Church." 127 Drawing upon the stereotype of the Smart Jew, Barry stated that "the Catholic spirit and the Hebrew genius" have been locked in unending conflict as a result of "Israel's rejection of the Gospel." The oppression of Paul and his fellow Christians was just the beginning. "Israel," he informed his readers, "did surely fulfil the prophets when it gave birth to Christ." It is doing so yet again, Barry concluded, but this time it is paving the way not for Christ but for the Antichrist. Following Manning, he suggested that only the "remnant of the Christian society" can hold back the "antichristian power." Barry did not however hold much hope for the coming battle, for he believed that the Christian remnant had been torn apart by the Reformation and that the Protestants had deserted the battlefield. ${ }^{128}$ Manning's so-called prophetic warning was not the only one that Barry listened to. He also detected "prophecies" and "forecasts" about the Jews in the works of Benjamin Disraeli, ${ }^{129}$ Édouard Drumont, Peter Kropotkin and Friedrich Nietzsche. ${ }^{130}$ According to Nietzsche, one of Barry's supposed prophets, "that the Jews could, if they wanted . . quite literally rule over Europe, is certain; that they are not planning and working towards that is equally certain." 131 Alluding to this passage, Barry stated that "according to Nietzsche, the Jews, thirty-five years ago, could have seized the supremacy over Europe. They did not want it then, he believed. They surely want it now." 132

Barry returned to the Antichrist a few years later. Again referring to scriptural teaching about "the 'Man of Sin"” and Manning's interpretation of prophecy, he concluded that the events in Russia, the triumph of atheism over Christianity, demonstrate that the Antichrist is "now in the world." Barry observed that the Church Fathers predicted "the persistence of

124 Barry, "Sign of the Times I" and Manning, The Temporal Power, 115-116.

${ }_{25}$ Manning, The Temporal Power, 115.

126 Barry, "Sign of the Times I."

127 William Barry, "Sign of the Times II," Catholic Times, 6 November 1920, 7 and Manning, The Temporal Power, 146. Belloc made a similar observation. Belloc stated that "there are two, and only two, organized international forces in Europe to-day with a soul and identity in them. One is the Catholic Church, and the other is Jewry." Belloc, The Fews, 172.

128 Barry, "Sign of the Times II."

${ }^{129}$ According to Barry, Disraeli was a commendable Jew, who recognised the significance of race and secret societies. Barry nevertheless stressed that "English he never could altogether be; he looked, thought, and felt as an Israelite, moving about in a foreign world." William Barry, "Disraeli the Jew," Catholic Times, 24 July 1920, 7.

${ }^{130}$ William Barry, "Sign of the Times III," Catholic Times, 13 November 1920, 7.

131 Friedrich Nietzsche, Beyond Good and Evil: Prelude to a Philosophy of the Future, trans. R.J. Hollingdale (1886; repr., London: Penguin, 1990), §251.

132 William Barry, "Sign of the Times IV," Catholic Times, 20 November 1920, 7. 
Israel though scattered among all peoples" and "their enmity to the Church, their certain rise to power in Christendom, and their strange alliance with the 'Man of Sin,' who will, however, be himself a Jew, though most likely a renegade from his faith and tribe." According to Barry, this was an amazing "stroke of divination," which has been "accomplished in Russia to the letter." Karl Marx, Barry suggested, was "the false prophet of the Apocalypse," and Lenin, "a monster of blood and impiety." "Lenin," Barry suggested, "is an unspeakable murderer, a usurper of all public rights, God's enemy, man's oppressor." In other words, Lenin was the Antichrist and Marx was his evangelist. According to Barry, Cardinal Manning regarded "the Revolution," "the evil elements in emancipated Judaism" and "the assailants of Papal Rome," to be "associated in a common Unholy Alliance." Barry concluded that "history justifies the forecast which he made of a coming Antichrist, now looming large upon our Christian inheritance." 133

The Jewish Antichrist was a less prominent theme in the English Catholic discourse than the Pharisee and the Christ-Killer. References to the Antichrist, the Lawless One, the Man of Sin, princes of darkness, Satan, servants of the Devil and other malign spirits, were quite common in English Catholic newspapers, but in most cases these were discussed without mentioning Jews. Manning and Barry's formulation of the Jewish Antichrist myth was however endorsed and adopted by the Month. An editorial in the Month approved of Barry's "notable article." According to the Month, "in Soviet Russia Manning's prophecy has actually been realised." The editorial stated that "Antichrist, in the person of those apostate Jews, is already in power" and "Marx, another apostate Jew, is his evangelist, and Christianity, especially the Catholicism of Rome, is the object of his bitterest hatred." 134 The Jewish Antichrist was also a theme in English Catholic constructions of the Luciferian Freemason.

\section{The Luciferian Freemason}

The Diana Vaughan hoax was a long-running anti-Masonic episode which came to its dramatic conclusion in 1897. In 1885, Léo Taxil (formerly Marie Joseph Gabriel Antoine Jogand-Pagès), a French writer, lapsed Catholic and expelled Freemason, started to invent elaborate stories about devil worship and sinister rituals in certain Masonic lodges. Taxil wrote a series of fanciful anti-Masonic works such as L'Antéchrist ou l'origine de la franc-maçonnerie (the Antichrist and the origins of Freemasonry). Taxil pretended to be a repentant Catholic. Among the admirers of his writings were the Bishops of Grenoble, Montpellier, Coutances and Port-Louis and the editors of La Croix, L'Univers, and La Civiltà Cattolica. ${ }^{135}$ There were also reports that Taxil had a personal meeting with Leo XIII in $1887 .{ }^{136}$ Though it is difficult

\footnotetext{
133 William Barry, "Against God and his Christ," Catholic Times, 28 April 1923, 9.

134 "Antichrist in Russia," Topics of the Month, Month, CXLI (June 1923), 552-553. See also "Anti-Christ in Russia at Home," Topics of the Month, CL (July 1927), 65-67 and "Anti-Christ in Russia and Mexico," Topics of the Month, CL (November 1927), 443.

135 See Stephen Wilson, Ideology and Experience: Antisemitism in France at the Time of the Dreyfus Affair (Oxford: Littman Library of Jewish Civilisation, 2007), 546.

${ }^{136}$ A meeting with the pope was reported in the entry for Léo Taxil in Pierre Larousse, ed., Grand Dictionnaire Universel du XIXe Siècle, Deuxième Supplemént (Paris: Administration du Grand Dictionnaire Universel, [1890]), 1903. Taxil also mentioned the meeting when he gave the speech in April 1897 in which he admitted that Diana Vaughan and Palladian Freemasonry were a fabrication of his own devising. His announcement that the affair had been a hoax was reported in a number of English and French newspapers. See for example "The Diana Vaughan
} 
to verify whether this meeting really occurred, Leo XIII certainly expressed a similar if less colourful antipathy towards the Freemasons in official documents. ${ }^{137}$

In the 1890s, Taxil crafted the memoirs of Diana Vaughan, a fictitious female apostate from "Palladian" Freemasonry whom he claimed to know and represent (the Mémoires d'une Ex-Palladiste). ${ }^{138} \mathrm{He}$ also wrote Le Diable au XIX ${ }^{\mathrm{e}}$ siècle under the pseudonym of Dr Bataille. These works contained elaborate tales about a circle of Satanic Freemasonry, the so-called Palladian lodges, which had supposedly been set up by Albert Pike. ${ }^{139}$ The tales included bizarre accounts of host desecration, magical rites which employed "the skulls" of "martyred missionaries" and the literal manifestations of Lucifer, Asmodeus and a number of other demons. ${ }^{140}$ In August 1895, the Tablet stated that "much attention has recently been called to the doings of the various sects of Freemasons abroad by the sudden conversion of one of their high priestesses, Miss Diana Vaughan, ex-Grand Mistress of the Luciferians or Palladians." Taking the Mémoires d'une Ex-Palladiste at face value, the Tablet reported that prior to converting to Catholicism, Diana had tried, unsuccessfully, to set up a reformed sect of Palladium Freemasonry, because despite "the strange perversion of mind" which had led her to "the worship of Lucifer," she was not blind to the "degrading character of the rites practised by her fellow-worshippers." "In 1896, Arthur Waite published a study, Devil Worship in France or the Question of Lucifer, which refuted the myth of the existence of "Palladian" Freemasonry. ${ }^{142}$ The Tablet responded in October with an equivocal endorsement of his efforts. The paper first responded to his refutation in a book review. The Tablet concluded that Devil Worship in France is a "clever but not convincing book of an honourable opponent." According to the book review, Waite succeeded in casting some doubt upon the lady herself, Miss Diana Vaughan, but not the evidence of Satanism in Masonic lodges. The paper

Case," Times, 21 April 1897, 6. A transcript of Taxil's speech, along with interjections from the audience, was recorded in Le Frondeur, 25 April 1897. The speech outlined the efforts Taxil adopted to integrate himself into the Church (including false confessions), his audience with the pope, details of the letters of encouragement he received from Catholic newspapers and bishops, the pseudonyms he adopted and the volunteers who assisted him in his hoax. An English translation is provided in Alain Bernheim, A. William Samii and Eric Serejski, "The Confession of Léo Taxil," Heredom: Transactions of the Scottish Rite Research Society, 5 (1996), 137-168. See also Wilson, Ideology and Experience, $578 \mathrm{n} 380$.

${ }^{137}$ On 20 April 1884, Leo XIII promulgated an encyclical, "Humanum Genus," which condemned Freemasonry. This can be accessed via the Vatican website, www.vatican.va. In 1902, Leo sent out an apostolic letter, "Annum Ingressi." The apostolic letter declared that the very purpose of Freemasonry is to "urge war against God and against His Church." The letter stated that Freemasonry embraces in its "vast net almost all the nations, and allying itself with other sects which it sets in motion by means of hidden strings, first attracting and keeping its hold on its members by means of the advantages which it secures to them, binding governments to its purposes, now by promises, now by threats, this sect has succeeded in permeating all classes of society." It stated that Freemasonry is "filled with the spirit of Satan, who . . . knows how, on occasion, to transform himself into an angel of light." Freemasonry thus puts forward "a humanitarian programme" but in reality it "sacrifices everything to its sectarian designs." Leo XIII, "Annum Ingressi," 18 March 1902. A copy of this apostolic letter can be found in the Leeds diocesan archives: Apostolic Letter of His Holiness Pope Leo XIII, 1902, Acta Ecclesiae Loïdensis, vol. XII, Leeds Diocesan Archives.

138 Diana Vaughan was the name of Taxil's secretary/assistant.

139 Albert Pike was a prominent lodge master in American Freemasonry.

140 See Arthur Edward Waite, Devil Worship in France or the Question of Lucifer (London: George Redway, 1896), 67, 104-109, 144-156, passim.

141 "The Anti-Masonic Congress," Tablet, 17 August 1895, 250-251.

142 Waite, Devil Worship in France. Waite was a lapsed Catholic with an interest in mysticism. He was a member of the Hermetic Order of the Golden Dawn. He became a Freemason in 1901. R. A. Gilbert, "The Masonic Career of A.E. Waite," Ars Quatuor Coronatorum, 99 (1986), 88-93. 
remained "profoundly convinced of the strict justice of the Church's attitude towards Masonry, strongly persuaded that there is an inner Masonry whose workings are unknown to the general run of Masons," and "that Satanism is practised under circumstances at least pointing to Masonic association." "The net result," the review concluded, "is that we should receive all evidence as to Palladian masonry with caution, and suspend a final judgement until we have exacted evidence as irrefragable as the nature of the case admits." "143 A week later, the Tablet reported that the Anti-Masonic Congress ${ }^{144}$ had set up a "special committee" to deal with the "burning questions" relating to Diana Vaughan. On the one hand the report acknowledged that the "fantastic and legendary accretions" in the "writings published under the pseudonym of "Diana Vaughan" may have "unduly discredited" some of the more sober reflections on the anti-religious hostility and "demonolatry" of Freemasonry. However, the report went on to state:

That there is in France a sect devoted to the worship of Lucifer, as the champion of rebellious humanity, is, we believe, a well-attested fact, and the propagation of this diabolical creed has been ascribed by M. Taxil and M. Ricoux to an inner ring of the Masonic body called Palladic Masonry.

The report then referred back to the review of Devil Worship in France which appeared in the previous issue of the Tablet, stating that "we reviewed in these columns last week the work in which Mr. Waite, on behalf of Masonry, traverses and impugns these statements, but without any conclusive refutation of their general drift." Referring to Waite's volume, the Tablet concluded that in attempting to refute the evidence of a connection between Satanic sects and Freemasonry, "the Scotch verdict of 'Not proven' is . . . the most favourable that can be registered on his review of the situation." 145 The editor of the Tablet was, it seems, reluctant to dismiss the core accusations of Satanic Freemasonry found in Mémoires d'une Ex-Palladiste and Le Diable au XIX ${ }^{\mathrm{e}}$ siècle. Significantly, Diana Vaughan was not the only item on the agenda at the Anti-Masonic Congress. The role played by the Jews in the Masonic movement was also discussed at the Congress. One speaker claimed that the "leading spirits of the craft were Hebrews" and that as Freemasonry is entirely in the hands of the Jews, "Anti-Semitism was the most efficacious weapon with which to counteract its pernicious effects." "For this reason," the speaker continued, "all true Catholics should support the Anti-Jewish crusade." $" 146$

\footnotetext{
143 "Devil Worship in France," review of Devil Worship in France or the Question of Lucifer, by Arthur Edward Waite, Tablet, 3 October 1896, 529-530. Citing passages from this review in the Tablet, R. A. Gilbert concluded that Waite's book was "well received, even by the Catholic press." R. A. Gilbert, "Introduction," in Arthur Edward Waite, Devil Worship in France with Diana Vaughan and the Question of Modern Palladism (Boston: Weiser Books, 2003), xxi (see also pages $301-302)$.

${ }_{144}$ The Anti-Masonic Congress was an annual gathering inaugurated in 1895 to enable Catholics from different countries to meet and rally their forces against the threat of Freemasonry. "The Anti-Masonic Congress," Tablet, 17 August 1895, 250-251. The Anti-Masonic Congress was still debating the existence of a conspiracy to destroy all nations and found a universal Masonic republic in their place in 1912. It was suggested that Freemasons planned to break down national identities by replacing all other languages with Esperanto. "Esperanto and Freemasonry," Catholic Herald, 13 April 1912, 7.

${ }^{145}$ Report of the Anti-Masonic Congress," Tablet, 10 October 1896, 565-566. Arthur Waite discussed the AntiMasonic Congress and its consideration of Diana Vaughan's memoirs in "Diana Vaughan and the Question of Modern Palladism," n.d., Item A699 (PAL) WAI fol., pp.52-60, Library and Museum of Freemasonry, London. This manuscript was a supplement to Waite's Devil Worship in France or the Question of Lucifer (1896).

146 "The Anti-Masonic Congress," Jewish Chronicle, 9 October 1896, 17.
} 
As the Tablet was sympathetic to the myth of Palladian Freemasonry, it unsurprising became the main forum in England for individuals to share their views about the Diana Vaughan Affair. ${ }^{147}$ Diana Vaughan had some fervent admirers. One reader, Herbert Jones, a member of the Canons Regular of the Lateran, ${ }^{148}$ expressed his admiration for the "nobleminded lady who has left the Satanic Society." 149 According to Jones, those who doubt the existence of Miss Vaughan and "talk of deception in the matter are themselves the real dupes of Jew Masons." He cited a letter from the Bishop of Grenoble which stated that Nathan, Freidel and other prominent Freemasons have been "sent about to cast discredit on Miss Vaughan's damaging attack on masonry." According to Jones, Nathan is an English Jew and the "present Grand Master of French and Italian Freemasonry," ${ }^{50}$ whilst "Freidel, the other Masonic deceiver, ... has been very busy spreading the report that Diana Vaughan is a nonentity." Jones also stated that "it is well known in Holland that ... a certain M. Rosen, in reality a spy of the Italian Archmason Lemmi, has been visiting many Dutch ecclesiastics and repeating to them that Diana Vaughan is a myth." Jones claimed that Rosen "pretends to be a convert from Masonry," but in reality he is a "Jewish Rabbi and a leading mason." Jones lamented that there are "credulous Catholic journalists" who are being convinced by these Freemasons that Diana Vaughan does not exist. "It is," he concluded, "a Masonic plot to cast discredit on the damaging revelations of Masonic devilry revealed by Diana Vaughan." ${ }^{51}$ Another reader of the Tablet, Francis Merrick Wyndham, a convert from Anglicanism who went on to become Canon of Westminster Cathedral, sent many letters to the Tablet contributing "evidence" of Diana Vaughan's existence. ${ }^{152} \mathrm{He}$ also published a booklet in the same year containing extracts from Masonic texts to demonstrate that a person from any religion, including "a Jew or a Mohammedan," can be admitted to Freemasonry just as long as they believe in the Great Architect of the Universe. He stated that it logically follows that "a Luciferian or a Satanist" can be admitted to Freemasonry, just as long as he accepts that "Lucifer or Satan is the Great Architect of the Universe." 153 In response to an announcement that Diana Vaughan would soon make a public appearance, another Catholic advocate of the lady expressed hope that when she appears, sceptical journalists will not continue to "attack a defenceless woman" but rather "give her a fair hearing." 154

Credulity over Diana Vaughan's revelations was not confined to the pages of the Tablet.

147 For letters discussing Diana Vaughan and Palladian Freemasonry, see: Tablet, Letters to the Editor: 24 October 1896, 660-661; 2 January 1897, 21-23; 9 January 1897, 64-65; 16 January 1897, 102; 23 January 1897, 138-139; 20 February 1897, 299; 6 March 1897, 379; 10 April 1897, 577; 17 April 1897, 617-618; 24 April 1897, 657.

148 A Roman Catholic religious order based in Rome but with a presence in England.

149 Herbert Jones, Letters to the Editor, Tablet, 10 April 1897, 577.

${ }^{150}$ Jones probably had Ernesto Nathan in mind, who was Jewish and a Freemason. He became mayor of Rome in 1907.

${ }^{151}$ Herbert Jones, Letters to the Editor, Tablet, 23 January 1897, 138-139.

152 Francis M. Wyndham, Letters to the Editor, Tablet: 2 January 1897, 21-22; 16 January 1897, 102; 23 January 1897, 139; 20 February 1897, 299; 10 April 1897, 577. Francis Merrick Wyndham was born into an illustrious family. He was the son of Colonel Charles Wyndham, the 3rd Baron Leconfield, and Elizabeth Scott, daughter of the 4th Lord Polwarth. Wyndham took Anglican Orders but converted to Roman Catholicism in 1868. He was ordained priest of the Congregation of Oblates of St Charles in 1871, was elected Superior of the Bayswater Community in 1891 and was appointed Canon of Westminster in 1909. See F. C. Burnand, ed., Catholic Who's Who E Tear Book, 1915 (London: Burns \& Oates, 1915), 478.

${ }_{153}$ Francis M. Wyndham, Anti-Masonic Catechism of Freemasonry (London: Washbourne, 1897), 5-7.

154 Archibald J. Dunn, Letters to the Editor, Tablet, 6 March 1897, 379. 
Baroness Mary Elizabeth Herbert, a close friend and associate of Cardinal Archbishop Vaughan, wrote a review article in the Dublin Review about two books by Domenico Margiotta on the subject of Freemasonry and the worship of Lucifer. ${ }^{155}$ Margiotta was one of Léo Taxil's "auxiliary" assistants. ${ }^{156}$ Herbert announced that "in spite of the superhuman efforts to conceal their proceedings made by the freemasons throughout the world," the "true nature" of Freemasonry is becoming known through the revelations of former members "of the sect." She accepted Margiotta's claims that Adriano Lemmi, a prominent Italian Freemason, was a convicted thief, a secret Jew convert and a Satanist schismatic (Margiotta claimed that a rift existed in Freemasonry between the Palladian "Luciferians" and the Satanic schismatics). She also accepted at face value his lengthy discussion of Diana Vaughan's "noble and generous character" and her consistent refusal to "profane a consecrated Host," even though this was, according to Margiotta, insisted upon by "the order." 157

On 19 April 1897, a large audience, consisting largely of Catholics and Freemasons, gathered in the auditorium of the Société Géographique in Paris in order to finally meet Diana Vaughan. The audience was consequently stunned when Taxil rather than Diana Vaughan appeared on the stage and announced that the whole tale of Palladian Freemasonry was a hoax. Diana Vaughan, the illusive ex-Grand Mistress of the Luciferians, did not exist. Taxil thanked the Catholic bishops and editors who had encouraged his exposés of Satanic Freemasonry. ${ }^{158}$ The reaction of English Catholics was mixed. Some were embarrassed about the credulity of their fellows. Two weeks before the hoax was confessed, an anonymous book reviewer in the Month stated that he found it "quite inexplicable" that in England, "Catholics should be found to swallow down any extravagant and prurient absurdity which M. Léo Taxil may choose to invite them to believe about Freemasonry." The reviewer found it humiliating that "respected ecclesiastics" defend such absurdities in "our public journals." 159

${ }_{155}$ Mary Elizabeth Herbert, the Baroness Herbert of Lea, was an English Catholic philanthropist and a prolific author of religious books and pamphlets. She converted from Anglicanism to Catholicism in 1866, largely under the influence of Cardinal Manning. She also became a close friend of Cardinal Vaughan. She was the foremost benefactor to Vaughan's project to create the Foreign Missionary College at Mill Hill. See Robert O'Neil, Cardinal Herbert Vaughan: Archbishop of Westminster, Bishop of Salford, Founder of the Mill Hill Missionaries (Tunbridge Wells, Kent: Burns \& Oates, 1995), 158-162, 174-176, passim.

156 Taxil described Margiotta as an "unexpected auxiliary" rather than an "accomplice," because in the beginning he was "one of the hoaxed." According to Taxil, when Margiotta realised his mistake, he decided to play along and "declare himself an accomplice," rather than be ridiculed as "a blind volunteer." Bernheim, Samii and Serejski, "The Confession of Léo Taxil," Heredom, 159.

${ }_{157}$ Mary Elizabeth Herbert, review of Adriano Lemmi: Supreme Head of the Freemasons and Le Palladisme; Or the Worship of Lucifer, both books by Domenico Margiotta, Dublin Review, CXVIII (January 1896), 192-201.

158 See Bernheim, Samii and Serejski, "The Confession of Léo Taxil," Heredom, 137-168.

159 "The Diana Vaughan Hoax," review of La Fin d'une Mystification, by Eugène Portalié, Month, LXXXIX (April 1897), 442. The reviewer pointed to claims in Diana Vaughan's memories about the arrival of the Antichrist and the election of a Pope who would renounce Christ for Lucifer. He wrote a long letter to the Tablet on 13 April 1897 in response to letters by Francis Wyndham and Herbert Jones. Wyndham and Jones had accused him of not reading Diana Vaughan's memoirs carefully, as the references to the Antichrist in her memoirs were not her views but those of "the Palladists." For the two letters, see Letters to the Editor, Tablet, 10 April 1897, 577. The reviewer explained that he had focused on the Antichrist myth because being a familiar Christian narrative it was easy to discuss succinctly. He went on to summarise and dismiss some of the more absurd narratives about so-called Palladian Freemasonry, such as "the birth story of Sophia Walder, begotten and suckled by a devil," "the embracing of the chaste Diana by the beautiful demon Asmodeus," "the profanation of hosts" and "the blasphemous parodies of Masses and devotions." Reviewer, Letters to the Editor, Tablet, 17 April 1897, 617-618. The Tablet later acknowledged "the sagacity" which led to the Month seeing through the hoax. Notes, Tablet, 24 April 1897, 648. 
Herbert Thurston was no friend to Freemasonry. ${ }^{160}$ Nevertheless, in 1898, as part of an article which discussed the ritual murder accusation, he stated that the "Diana Vaughan episode" was a "pitiable exposure of credulity." He concluded that the end of the antiMasonic episode, the "disappearance into thin air of the impalpable 'luciferians," seems only to have "added new zest to the pursuit of the unquestionably very real and substantial Israelites." ${ }^{161}$ Other Catholics were angry. The Tablet directed its anger at Taxil. ${ }^{162}$ The Universe also focused on the "discreditable" actions of Taxil, regarding it as no surprise that he only "narrowly escaped personal chastisement at the hands of his dupes." "163 Conversely, the Paris correspondent for the Catholic Herald vented his frustration on the credulous Catholics who had lapped up the "ridiculous and grotesque stories" about Palladian Freemasonry and the Catholic newspapers that swallowed the alleged revelations as if they were gospel. The correspondent reported that every absurd story about Diana Vaughan was raised "to the height of a dogma" and Catholics who refused to accept them had been branded as "a traitor to the Church and perhaps nearly a Freemason, too." 164

After Taxil's announcement, narratives about Palladian and Satanic Freemasonry largely faded from English Catholic discourse. ${ }^{165}$ They did not however completely disappear. Colonel James Ratton, an English Catholic, retired army doctor and author, helped to keep them alive for a little while longer. ${ }^{166}$ In 1901, he published X-Rays in Freemasonry. This repeated traditional stereotypes about the anti-Christian nature of Freemasonry and its alleged war against the Church. It repeatedly emphasised Jewish involvement in Freemasonry and informed readers that the Jews killed Christ and have clung onto their "anti-Christian"

${ }^{160}$ Herbert Thurston published a number of articles and books which were highly critical of Freemasonry, though they were written without the hysterical diabolisation of some of his contemporaries. His main concerns seem to have been that Freemasonry was deistic, secretive, revolutionary, conspiratorial, anti-Christian, anti-clerical and anti-Catholic. See for example Herbert Thurston, Freemasonry (London: Catholic Truth Society, 1921); Herbert Thurston, "The Popes and Freemasonry," Topics of the Day, Tablet, 27 January 1923, 108; Herbert Thurston, "The Church's International Enemy," Month, CXLVIII (November 1926), 385-397; Herbert Thurston, No Popery: Chapters on Anti-Papal Prejudice (London: Sheed and Ward, 1930), 55-86. His criticisms were mainly directed at "continental" Freemasonry. However, he observed that whilst English Freemasonry was "convivial," "philanthropic" and not driven by an anti-clerical animus, when it came to the practices of their continental brethren, they were only slightly less culpable as they simply "shrugged their shoulders and looked another way." Thurston, "The Popes and Freemasonry," 108.

161 Thurston, "Anti-Semitism," 562. Thurston wrote a letter to the Tablet in January 1897, the nature of which suggested that he already believed the Diana Vaughan revelations were "an exploded myth." Herbert Thurston, Letters to the Editor, Tablet, 2 January 1897, 22-23.

162 Notes, Tablet, 24 April 1897, 648; "The End of a Deception," News from France, Tablet, 24 April 1897, 656.

163 "The Diana Vaughan Case," Universe, 24 April 1897, 4.

164 Paris Correspondent, Our Paris Letter, Catholic Herald, 30 April 1897, 4.

165 Though articles about the influence of Satan and Antichrist, especially in Russia and Mexico but also in modernist and spiritualist movements in the West, continued to be quite common in English Catholic periodicals.

${ }^{166}$ Ratton was by no means considered eccentric. He published a number of books on diverse, not exclusively religious subjects. Several of his books were however concerned with the Antichrist and the apocalypse. The Catholic Who's Who observed that Ratton had "made a special study of the Apocalypse, and is the author of several wellconsidered works." F. C. Burnand, ed., Catholic Who's Who \& Year Book, 1908 (London: Burns \& Oates, 1908), 335. During the early years of the twentieth century, Ratton accepted the myth of the Jewish Antichrist. Ratton's views about the Antichrist and the apocalypse did however change significantly sometime between 1904 and 1914 . He still referred to the Jews' rejection of Christ, but he no longer believed in the Jewish Antichrist. He argued that Nero was the Antichrist prophesised by Daniel, and that all subsequent millenarian traditions of the Antichrist are based on the exegetical writings of St. Irenaeus (which he suggests were faulty). James Ratton, Antichrist: An Historical Review (London: Burns and Oates, 1917); James Ratton, "Antichrist," Letters to the Editor, Universe, 4 December 1914,4 . 
principles and ideals ever since. ${ }^{167}$ According to Ratton, these ideals include "the expectation of another Messiah, who, we know, will be Antichrist." He argued that Freemasonry is Satanic and that "the Bnai-Bérith," whose goal he suggested was to dominate all forms of Freemasonry and re-establish King Solomon's Temple, is a branch of Jewish Freemasonry closed to non-Jews with the exception of visits by the "Inspectors General of the Palladium." 168 Ratton added new material when he republished X-Rays in 1904. He argued that Zionism is of interest because it has been prophesised that when the Jews return to Jerusalem, "anti-Christ will appear in their midst." According to Ratton, Freemasonry, guided by the Jews, is preparing to move its headquarters to Jerusalem, and when the "BnaiBérith" joins them, "then will anti-Christ appear in alliance with the Sovereign Pontiff of Freemasonry, and incite the international Masonic forces to persecute the Church in such fashion as has never been before." 169 Montague Summers, an eccentric convert to Catholicism, continued to argue that Albert Pike, the alleged founder of Palladian Freemasonry, had been the Grand Master of "societies practising Satanism." ${ }^{170}$ Father Cahill, an Irish Jesuit, argued in Freemasonry and the Anti-Christian Movement (1929), that Freemasonry is associated with occultism, Satanism, the Antichrist, Judaism, Jewish rites, the Cabala and a Judaeo-Masonic anti-Christian movement. ${ }^{171}$ He concluded that the Diana Vaughan hoax was probably a plot to discredit the "reliable evidence" that Freemasonry is associated with Satanism. ${ }^{172}$ According to the Catholic Times, Father Cahill, unlike prominent Freemasons, does not expect readers to accept "even a single point" from his book on faith, for he "proves everything." 173

\section{Conclusion}

The scriptural authority of the New Testament has given the myths about the Pharisee and the Christ-Killer a highly resilient quality. The most prominent source of these myths in English Catholic discourse during the late nineteenth- and early twentieth-century were the sermons, pastoral letters and public addresses of priests, bishops and archbishops. Hostility towards contemporary Jews was probably not intended by most of the authors of these public addresses. The Christ-Killer and the Pharisee often served as caricatures to represent everything reprobate, obsolete, non-Christian or anti-Christian. They were thus convenient symbols which could be drawn upon to contrast with Christian virtues and illustrate nonChristian vices. ${ }^{174}$ However, whilst many of the authors of the sermons and pastoral letters probably had biblical figures in mind rather than contemporary Jews, there was an

\footnotetext{
${ }^{167}$ James Ratton [A. Cowan, pseud.], X-Rays in Freemasonry (London: Effingham Wilson, 1901), passim.

168 Ibid, 104-123.

169 James Ratton [A. Cowan, pseud.], X-Rays in Freemasonry, revised edition (London: Effingham Wilson, 1904), 309-310, 346-350. Though published using a pseudonym, Ratton took credit for X-Rays in Freemasonry in Ratton, Antichrist, v.

${ }^{170}$ Summers, The History of Witchcraft, 8.

${ }^{171}$ Edward Cahill, Freemasonry and the Anti-Christian Movement, 2nd ed. (Dublin: M. H. Gill, 1930), 67-95. The first edition was published in 1929 .

172 Ibid, 70-71.

173 "Eminent Jesuit's Book Evokes Wide Public Interest," Catholic Times, 8 November 1929, 6.

${ }^{174}$ For a discussion about the symbolic function of the Jew in Christian "anti-Judaism," see Miriam S. Taylor, Anti-fudaism and Early Christian Identity (Leiden: E.J. Brill, 1995), 127-187.
} 
essentialistic quality to these representations and it seems likely that in many cases little consideration was given to any such distinction. In some cases the sermons were framed in such a way as to generalise Jewish villainy to the "Jewish race", past and present. Furthermore, certain authors, such as the Chesterton brothers, William Barry and Charles Diamond, were happy to combine the Jewish diabolist from traditional Christian myths with modern stereotypes of Jewish villains in order to create their own distinctive constructions of the Jew. ${ }^{175}$

The Pharisee and the Christ-Killer were not the only representations of the mythologized Jew in English Catholic discourse. The Antichrist, Man of Sin or Lawless One, was described as a very real and very frightening individual rather than merely a symbol or spirit of the times and he was called upon to explain a number of contemporary evils. The Antichrist was often invoked independently of representations of the Jew. Whilst the Jewish Antichrist was a relatively rare representation of the Jew, it was found in the narratives of some prominent individuals, including Father Henry Manning (subsequently Cardinal Archbishop of the English hierarchy) and Canon William Barry. Barry wrote numerous articles about the Jews and the Jewish problem. Citing Manning's lectures as if they were prophetic forecasts, Barry combined the myth of the Jewish Antichrist with contemporary stereotypes of Jewish greed, secrecy, disloyalty, Bolshevism and anti-Christian hostility, to produce a construction of the Jew that was second only to constructions by the Catholic Herald for the multiplicity of its themes. The Month supported Barry's construction of the Jewish Antichrist, suggesting that he was already in power in Russia and that Marx had been his evangelist.

Freemasons, like the Jews, were also associated with the prophecy of the Antichrist. They were also accused of devil worship and Satanic practices. The Tablet equivocated about the specifics of the Diana Vaughan revelations but it remained "profoundly convinced" that an inner circle of highly secretive Satanic Freemasonry existed. However, whilst these accusations of literal diabolism were found in letters and articles appearing in The Tablet and Dublin Review during the Diana Vaughan Affair, they were relatively rare after it was revealed to be a hoax. The embarrassment of the Diana Vaughan episode may explain why The Protocols of the Elders of Zion, when it appeared in England, was almost totally ignored by the English Catholic press. There was however little reprieve in the vilification of Freemasonry in the English Catholic discourse. Freemasons continued to be vilified, but the main accusations in the early twentieth century became provoking social unrest, inciting revolution, supporting Bolshevism, anti-clericalism, anti-Christianity, secrecy and plundering the Church in France, rather than Satanism (though accusations of Satanism by no means entirely disappeared). Many of these accusations and stereotypes were shared with the Jews. Constructions of the Jews and the Freemasons were often linked in a Jewish-Freemason camarilla, alliance or conspiracy. In some cases the Jews and the Freemasons were accused of waging a campaign to exonerate Alfred Dreyfus irrespective of his guilt or innocence, and exploiting the Dreyfus Affair to destroy the army and the Church. ${ }^{176}$

\footnotetext{
${ }^{175}$ Modern stereotypes of the Jew in English Catholic discourse by these authors are examined in Mayers, "From 'the Pharisee' to 'the Zionist Menace,"” ch.3.

${ }^{176}$ For a more thorough examination of constructions of the Jewish-Masonic camarilla in the English Catholic discourse, including an examination of the Dreyfus Affair and its aftermath, constructions of the Jew and the Freemason by the Catholic Federation, and responses to the Protocols of the Elders of Zion, see Mayers, "From 'the Pharisee' to 'the Zionist Menace,'” ch.4.
} 
One of the more troublesome myths that survived into the twentieth century, albeit often with some adaptation, was the ritual murder accusation. This accusation resulted in trials, convictions and massacres. Some prominent Catholic periodicals in Italy and France, most notably Civiltà Cattolica, ${ }^{177}$ but also L'Unita Cattolica, ${ }^{178}$ L'Univers, $^{179}$ Osservatore Romano ${ }^{180}$ and Osservatore Cattolico, ${ }^{181}$ embraced the myth of the Jewish ritual murder. As far as the editors of Civiltà Cattolica were concerned, the Jews murdered innocent Christian children to satisfy religious commandments. Conversely, English Catholic reformulations of the accusation were usually divorced from criticisms of Judaism as a religion. Though sometimes presented using polemical language and sometimes ostensibly as a defence of Jews, it was common in either case to argue that the Jews had murdered innocent Christian children, with all the paraphernalia of crucifixion and blood draining, but that this was neither sanctioned by Judaism nor necessitated by Jewish rituals. It was usually argued that such murders were the result of the odium fidei of fanatical Jews or that they had been committed by superstitious Jews who believed in the efficacy of innocent Christian blood for magical purposes. The myth of Jewish ritual murder did not cease to exist, but it survived by adapting itself (thus demonstrating the resilient but protean nature of the myth). The Ritual Murderer thus underwent a partial metamorphosis into alternative representations, such as the Fanatical Murderer and the Jewish Sorcerer. Despite a willingness to exonerate Judaism "as a system" from the charge of sanctioning the murder of Christians, it was, it seems, impossible to abandon the myth that the Jews had murdered innocent Christian children in various diabolic ways, in some cases in reenactment or mockery of the Passion.

It seems clear that representations of the Jew in the late nineteenth- and early twentiethcentury were not always modern in character. In the case of the English Catholic discourse, they were often pre-modern or anti-modern. Many existing studies of English antisemitism argue that by the late nineteenth century, constructions of the Jew based on traditional Christian myths had largely, though not entirely, been replaced by modern socio-political and racial forms of antisemitism. This study however demonstrates that traditional religious myths about the Jews continued to thrive and function in the English Catholic discourse. Their continued existence was not confined to a handful of narrative artefacts from a bygone era. The Jew was thus mythologized as the Pharisee, Christ-Killer, fanatical murderer, sorcerer and Antichrist. The Jew (and the Jewish Antichrist) was portrayed in conjunction with the Freemason, who was diabolized as a servant of Lucifer or Satan. In some cases the language used to describe the Jew and the Freemason drew upon a vocabulary which suggested an apocalyptic war between the forces of good and evil.

\section{ARCHIVAL SOURGES}

Birmingham Archdiocesan Archives, Birmingham, UK.

Leeds Diocesan Archives, Leeds, UK.

\footnotetext{
177 Klein, "Civiltà Cattolica on Ritual Murder"; Kertzer, The Popes Against the Fewes, 158-162, 234-236.

178 Kertzer, The Popes Against the Jews, 232-233.

${ }^{179}$ Ibid, 233-234.

${ }^{180}$ Ibid, 162-163, 217-218

181 Ibid, 163-165.
} 
Library and Museum of Freemasonry, London, UK.

Manchester Jewish Museum, Manchester, UK.

Salford Diocesan Archives, Manchester, UK.

Sion Centre for Dialogue and Encounter, London, UK.

Westminster Diocesan Archives, London, UK.

\section{BIBLIOGRAPHY}

\section{Primary Sources}

Newspapers and Periodicals: Academy, Catholic Herald, Catholic Times, The Cross, Daily News, Dublin Review, Jewish Chronicle, Month, New Witness, Tablet, Times, Universe. ${ }^{182}$

Abrahams, Israel. "Saint Hugh of Lincoln," Books and Bookmen, Fexirsh Chronicle, 12 August 1898.

Attwater, Donald. "Religious Conditions in Palestine," Month, CXLVIII (October 1926).

Barry, William. "Against God and his Christ," Catholic Times, 28 April 1923.

, "Disraeli the Jew," Catholic Times, 24 July 1920.

, "Sign of the Times I-IV," Catholic Times: 30 October 1920; 6 November 1920; 13 November 1920; 20 November 1920.

Belloc, Hilaire. The Jewes (London: Constable, 1922).

Cahill, Edward. Freemasonry and the Anti-Christian Movement, 2nd ed. Dublin: M. H. Gill, 1930, first edition published in 1929.

Chesterton, Cecil. "Israel and 'The Melting Pot,"” New Witness, 5 March 1914.

__, "A Letter from Mr. Zangwill," New Witness, 12 March 1914.

Chesterton, G.K., "The Diabolist," Daily Newes, 9 November 1907, 6. , "The Duel of Dr. Hirsch," in G. K. Chesterton, The Complete Father Brown Stories. 1914; repr., London: Wordsworth Classics, 2006. , The Everlasting Man. London: Hodder and Stoughton, 1925.

Herbert, Mary Elizabeth. Review of Adriano Lemmi: Supreme Head of the Freemasons and Le Palladisme; Or the Worship of Lucifer, both books by Domenico Margiotta, Dublin Review, CXVIII (January 1896).

Herford, R. Travers. What the World Owes to the Pharisees. London: George Allen \& Unwin, 1919.

Irenaeus. Five Books of S. Irenaeus, Bishop of Lyons: Against Heresies, trans. John Keble. Oxford: James Parker, 1872.

Knox, Ronald. "Angry?," The Cross, XVII, no. 12 (April 1927).

_ "Danger versus Safety," The Cross, XVIII, no. 2 (June 1927).

, The Mystery of the Kingdom. London: Sheed \& Ward, 1928.

Manning, Henry. The Temporal Power of the Vicar of Jesus Christ, 2nd ed. London: Burns \& Lambert, 1862.

Meir, Joseph Ben Joshua Ben. The Chronicles of Rabbi Foseph Ben Foshua Ben Meir, vol. I, trans. G. H. F. Bialloblotzky. London: Richard Bentley, 1835.

Pope, Hugh. "The European War and Spiritualism," Universe: 5 April 1917-27 April 1917.

Ratton, James. Antichrist: An Historical Review. London: Burns and Oates, 1917.

Ratton, James. [A. Cowan, pseud.] The X-Rays in Freemasonry. London: Effingham Wilson, 1901. , The X-Rays in Freemasonry, revised edition. London: Effingham Wilson, 1904.

182 Many of the articles cited from English Catholic newspapers and periodicals were anonymous. Only articles signed by the author are individually listed here. 
Sabatini, Rafael. Torquemada and the Spanish Inquisition. 1913; repr., Thirsk, North Yorkshire: House of Stratus, 2001.

Summers, Montague. The History of Witchcraft and Demonology. London: Kegan Paul, Trench, Trubner, 1926.

Thurston, Herbert. "Anti-Semitism and the Charge of Ritual Murder," Month, XCI (June 1898).

—, "The Church's International Enemy," Month, CXLVIII (November 1926).

—, Freemasonry (London: Catholic Truth Society, 1921).

—, The Life of Saint Hugh of Lincoln. London: Burns and Oates, 1898.

, "Mr. Rider Haggard and the Immuring of Nuns," Month, LXXX (January 1894).

, "The Myth of the Walled-up Nun," in Publications of the Catholic Truth Society, XXI. London: Catholic Truth Society, 1902. , No Popery: Chapters on Anti-Papal Prejudice. London: Sheed and Ward, 1930.

_- "The Popes and Freemasonry," Tablet, 27 January 1923.

_., "The Ritual Murder Trial at Kieff," Month, CXXII (November 1913).

Thurston, Herbert and Donald Attwater. Eds., The Lives of the Saints, 2nd ed., vol. VI. London, Burns Oates \& Washbourne, 1931

Thurston, Herbert, and Norah Leeson. Eds., The Lives of the Saints, 2nd ed., vol. III. London, Burns Oates \& Washbourne, 1931 .

Vaughan, Bernard. Society, Sin and the Saviour. London: Kegan Paul, Trench, Trübner, 1908.

Vaughan, John Stephen. "The Scourge of War," The Catholic Pulpit, Universe, 13 August 1915.

Waite, Arthur Edward. Devil Worship in France or the Question of Lucifer. London: George Redway, 1896.

Wyndham, Francis M. Anti-Masonic Catechism of Freemasonry. London: Washbourne, 1897.

\section{Secondary Sources}

Alderman, Geoffrey and Colin Holmes. "The Burton Book," Fournal of the Royal Asiatic Society of Great Britain E Ireland, Series 3, 18, no.1 (2008).

Aspden, Kester. Fortress Church. Leominster, Hertfordshire: Gracewing, 2002.

Bernheim, Alain, A. William Samii and Eric Serejski. "The Confession of Léo Taxil," Heredom: Transactions of the Scottish Rite Research Society, 5 (1996).

Burnand, F. C. Ed., Catholic Who's Who E Year Book, 1908. London: Burns \& Oates, 1908.

—, ed., Catholic Who's Who Ė Tear Book, 1915. London: Burns \& Oates, 1915.

Červinka, František. "The Hilsner Affair," in Alan Dundes, ed., The Blood Libel Legend. Madison, Wis.: University of Wisconsin Press, 1991.

Cheyette, Bryan. Constructions of "the Few" in English Literature and Society: Racial Representations, 18751945. Cambridge: Cambridge University Press, 1993.

Cohn, Norman. Europe's Inner Demons: The Demonisation of Christians in Medieval Christendom. 1975; repr., London, Pimlico, 2005.

- The Pursuit of the Millennium. 1957; repr., London: Pimlico, 1993.

- Warrant for Genocide. 1967; repr., London: Serif, 1996.

Crehan, Joseph. Father Thurston: A memoir with a bibliography of his writings. London: Sheed and Ward, 1952.

Cruise, Edward. "Development of the Religious Orders," in George Andrew Beck, ed., The English Catholics, 1850-1950. London, Burns Oates, 1950.

Edwards, Owen Dudley and Patricia J. Storey. "The Irish Press in Victorian Britain," in Roger Swift and Sheridan Gilley, eds., The Irish in the Victorian City. London: Croom Helm, 1985. 
Ehret, Ulrike. "Catholics and Antisemitism in Germany and England, 1918-1939," PhD thesis, University of London (2006).

Endelman, Todd M. The Fewes of Britain, 1656 to 2000. Berkeley: University of California Press, 2002. 1979

Felsenstein, Frank. Anti-Semitic Stereotypes: A Paradigm of Otherness in English Popular Culture, 1660-1830. 1995; repr., London: John Hopkins University Press, 1999.

Gilbert, R. A. "Introduction," in Arthur Edward Waite, Devil Worship in France with Diana Vaughan and the Question of Modern Palladism. Boston: Weiser Books, 2003.

_ "The Masonic Career of A.E. Waite," Ars Quatuor Coronatorum, 99 (1986).

Gilley, Sheridan. "Father William Barry: Priest and Novelist," Recusant History, 24, no.4 (October 1999).

Holmes, Colin. Anti-Semitism in British Society, 1876-1939. New York, Holmes \& Meier, 1979.

_-, "The Ritual Murder Accusation in Britain," Ethnic and Racial Studies, 4, no. 3 (July 1981).

Holmes, J. Derek. More Roman than Rome: English Catholicism in the Nineteenth Century. London: Burns \& Oates, 1978.

Jackson, Bernard. "Legalism," Fournal of Jewirsh Studies, XXX, no.1, Spring 1979.

Julius, Anthony, Trials of the Diaspora: A History of Anti-Semitism in England. Oxford: Oxford University Press, 2010.

Kennedy, Dane. The Highly Civilized Man: Richard Burton and the Victorian World. Cambridge, Mass.: Harvard University Press, 2005.

Kertzer, David I. The Popes Against the Jewes: The Vatican's Role in the Rise of Modern Anti-Semitism. New York: Vintage Books, 2002.

Klein, Charlotte. "Damascus to Kiev: Civiltà Cattolica on Ritual Murder," The Wiener Library Bulletin 27 (1974).

Kushner, Tony. The Persistence of Prejudice: Antisemitism in British Society During the Second World War. Manchester: Manchester University Press, 1989.

Larousse, Pierre. Ed., Grand Dictionnaire Universel du XIX Siècle, Deuxième Supplemént. Paris: Administration du Grand Dictionnaire Universel, 1890.

Leslie, Shane. Henry Edward Manning: His Life and Labours. London: Burns Oates \& Washbourne, 1921.

Maccoby, Hyam. A Pariah People: The Anthropology of Antisemitism. London: Constable, 1996.

- The Sacred Executioner: Human Sacrifice and the Legacy of Guilt. London: Thames and Hudson, 1982.

Matthew, H. C. G. and Brian Harrison. Eds., Oxford Dictionary of National Biography. Oxford: Oxford University Press, 2004.

Mayers, Simon. 'From 'the Pharisee' to 'the Zionist Menace': Myths, Stereotypes and Constructions of the Jew in English Catholic Discourse (1896-1929)," PhD thesis, University of Manchester (2012).

McInally, Mary. Edward Ilsley: Archbishop of Birmingham. London: Burns \& Oates, 2002.

Morris, Kevin L. "Fascism and British Catholic Writers 1924-1939," Chesterton Review, XXV, no.1\&2 (February 1999).

O'Neil, Robert. Cardinal Herbert Vaughan: Archbishop of Westminster, Bishop of Salford, Founder of the Mill Hill Missionaries. Tunbridge Wells, Kent: Burns \& Oates, 1995.

Nietzsche, Friedrich. Beyond Good and Evil: Prelude to a Philosophy of the Future, trans. R.J. Hollingdale. 1886; repr., London: Penguin, 1990.

Strack, Hermann L. The Jew and Human Sacrifice: Human Blood and Fewish Ritual, trans. Henry Blanchamp, 8th ed. New York: Bloch, 1909.

Taylor, Miriam S. Anti-fudaism and Early Christian Identity. Leiden: E.J. Brill, 1995.

Thompson, Paul. The Edwardians: The Remaking of British Society. 1975; repr., Chicago: Academy Chicago Publishers, 1985. 
Trachtenberg, Joshua. The Devil and the Fews: The Medieval Conception of the Few and its Relation to Modern Antisemitism. 1943; Philadelphia: Jewish Publication Society, 1983.

, Fewish Magic and Superstition. 1939; repr., Philadelphia: University of Pennsylvania Press, 2004.

Wilson, Stephen. Ideology and Experience: Antisemitism in France at the Time of the Dreyfus Affair. Oxford:

Littman Library of Jewish Civilisation, 2007.

Catholic Who's Who Ë Year Book, 1928. London: Burns Oates \& Washbourne, 1928.

Catholic Who's Who \& Year Book, 1933. London: Burns Oates \& Washbourne, 1933.

Who Was Who, 1929-1940. London: Adam \& Charles Black, 1941. 